\title{
Gaseous Fission Product Release During Storage at Various Temperatures for HTGR-Type Fuels
}

\author{
C. L. Fitzgerald \\ R. J. Shannon \\ V. C. A. Vaughen
}

\section{OAK RIDGE NATIONAL LABORATORY} OPERATED BY UNION CARBIDE CORPORATION - FOR THE DEPARTMENT OF ENERGY 


\section{DISCLAIMER}

This report was prepared as an account of work sponsored by an agency of the United States Government. Neither the United States Government nor any agency Thereof, nor any of their employees, makes any warranty, express or implied, or assumes any legal liability or responsibility for the accuracy, completeness, or usefulness of any information, apparatus, product, or process disclosed, or represents that its use would not infringe privately owned rights. Reference herein to any specific commercial product, process, or service by trade name, trademark, manufacturer, or otherwise does not necessarily constitute or imply its endorsement, recommendation, or favoring by the United States Government or any agency thereof. The views and opinions of authors expressed herein do not necessarily state or reflect those of the United States Government or any agency thereof. 


\section{DISCLAIMER}

Portions of this document may be illegible in electronic image products. Images are produced from the best available original document. 


\section{Printed in the United States of America. Available from National Technical Information Service U.S. Department of Commerce 5285 Port Royal Road, Springfield, Virginia 22161}

Price: Printed Copy $\$ 4.50$; Microfiche $\$ 3.00$

This report was prepared as an account of work sponsored by an agency of the United States Government. Neither the United States Government nor any agency thereof, nor any of their employees, contractors, subcontractors, or their employees, makes any warranty, express or implied, nor assumes any legal liability or responsibility for any third party's use or the results of such use of any information, apparatus, product or process disclosed in this report, nor represents that its use by such third party would not infringe privately owned rights. 
ORNL/TM-6409

Dist. Category UC -77

Contract No. W-7405-eng-26

CHEMICAL TECHNOLOGY DIVISION

HTGR Fuel Recycle Development Program (189a OH 045)

Reprocessing Development (Task 310)

GASEOUS FISSION PRODUCT RELEASE DURING STORAGE AT VARIOUS TEMPERATURES FOR HTGR-TYPE FUELS

C. L. Fitzgerald

R. J. Shannon

V. C. A. Vaughen

Date Published - July 1978

Note: This document contains information of a preliminary nature. It is subject to revision or correction and therefore does not represent a final report.

OAK RIDGE NATIONAL LABORATORY

Oak Ri.dge, Tennessee 37830

operated by

UNION CARBIDE CORPORATION

for the

DEPAR'L'MENT OF ENERGY

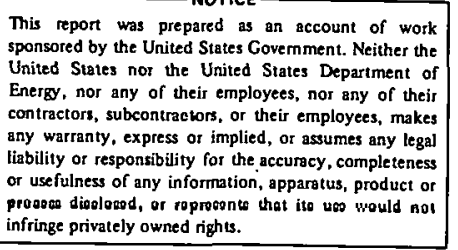

infringe privately owned rights. 


\section{THIS PAGE}

\section{WAS INTENTIONALLY \\ LEFT BLANK}


CONTENTS

ABSTRACT ............................ 1

1. INTRODUCTION . . . . . . . . . . . . . . . . . . . . 1

2. FUEL DESCRIPTION AND IRRADIATION DATA . . . . . . . . . 2

3. EXPERIMENTAL EQUIPMENT AND PROCEDURE . . . . . . . . . . . 2

4. EXPERIMENTAL RESULTS .................. . . 5

5. CONCLUSIONS . . . . . . . . . . . . . . . 16

6. REFERENCES .................... . . 18

7. APPENDIX..................... . . 19 
THIS PAGE

\section{WAS INTENTIONALLY LEFT BLANK}


 \\ LIST OF FIGURES}

PAGE

1. Experimental arrangement for storage experiment RTE-2-5. . 4

2. Release rates for ${ }^{85} \mathrm{Kr}$ and ${ }^{3} \mathrm{H}$ at ambient temperature

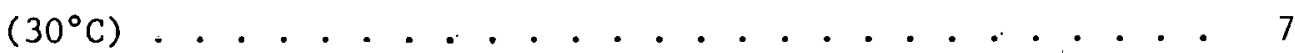

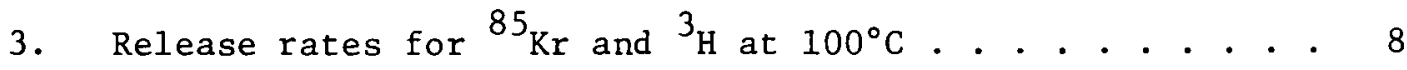

4. Release rates for ${ }^{85} \mathrm{Kr}$ and ${ }^{3} \mathrm{H}$ at $150^{\circ} \mathrm{C}$. . . . . . . . 9

5. Release rates for ${ }^{85} \mathrm{Kr}$ and ${ }^{3} \mathrm{H}$ at $200^{\circ} \mathrm{C}$. . . . . . . 10

6. Release rates for ${ }^{85} \mathrm{Kr}$ and ${ }^{3} \mathrm{H}$ at $300^{\circ} \mathrm{C} . . . . . . . .11$

7. Arrhenius plot of release rates during storage at various temperatures................ 12

8. Releases of ${ }^{85} \mathrm{Kr}$ and ${ }^{3} \mathrm{H}$ from stored HTGR fuel at various temperatures ( 30 to 100 days at temperature) . . . . . 14 
THIS PAGE

\section{WAS INTENTIONALLY LEFT BLANK}


1. Releases of ${ }^{85} \mathrm{Kr}$ and ${ }^{3} \mathrm{H}$ at various temperatures . . . . 6

2. Amounts of activity found on the absolute filter in the

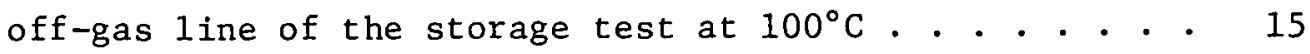

3. Amounts of residual activity found in the fuel body container by gamma scanning . . . . . . . . . . . 15

4. Amounts of activity found in fuel body container wash solutions . . . . . . . . . . . . . . . . 
GASEOUS FISSION PRODUCT RELEASE DURING STORAGE AT VARIOUS TEMPERATURES FOR HTGR-TYPE FUELS

C. L. Fitzgerald

R. J. Shannon

V. C. A. Vaughen

\section{ABSTRACT}

Measurements were made of gaseous fission product releases from an HTGR-type fuel body under conditions simulating storage at temperatures up to $300^{\circ} \mathrm{C}$. The fuel was a recycle test element containing BISO-BISO coated fuel particles which had been irradiated for 701 effective full-power days in the Peach Bottom HTCR.

Storage test temperatures were ambient (about $30^{\circ} \mathrm{C}$ ), 100,150 , 200 , and $300^{\circ} \mathrm{C}$. The initial release rates of $85 \mathrm{Kr}$ varied after each change in temperature. A fairly stable release rate was reached that increased from $\sim 60 \mu \mathrm{Ci} /$ day at ambient temperature to $\sim 1000 \mu \mathrm{Ci} /$ day after 30 days at $200^{\circ} \mathrm{C}$ and slowly decreased to about $200 \mu \mathrm{Ci} /$ day after 554 days at $200^{\circ} \mathrm{C}$. In the experiment at $300^{\circ} \mathrm{C}$, a final release rate of $4000 \mu \mathrm{Ci} / \mathrm{day}$ was attained after 66 days. The releases of $85 \mathrm{Kr}$ were followed for about two and one-half years.

The stabilized release rates for ${ }^{3} \mathrm{H}$ were $10.02 \mu \mathrm{Ci} / \mathrm{day}$ at ambient temperature, $20.750 \mu \mathrm{Ci} / \mathrm{day}$ at $200^{\circ} \mathrm{C}$ after 30 days, and $0.460 \mu \mathrm{Ci} / \mathrm{day}$ after 554 days. The final release rate at $300^{\circ} \mathrm{C}$ was about $30 \mu \mathrm{Ci} / \mathrm{day}$ after 66 days.

Over the lifetime of the experiment, $\sim 22 \%$ of the initial $85 \mathrm{Kr}$ inventory was evolved and swept out, and $\sim 4 \%$ of the initial $3 \mathrm{H}$ inventory was evolved and swept out. The activation energies calculated for the. $\mathrm{Kr}$ and ${ }^{3} \mathrm{H}$ evolution were $27.8 \mathrm{kcal} / \mathrm{mole}$ and $0,12.4 \mathrm{kcal} / \mathrm{mole}$, respectivel.y.

\section{INTRODUCTION}

The reprocessing of high-temperature gas-cooled reactor fuels to return the fissionable and fertile materials to the fuel cycle necessitates the existence of a storage facility for the spent fuel elements. The most economical manner to operate such a storage facility would be with the elements in unsealed containers, and with no treatment of the off-gas. Since the quantities of radioactive nuclides that can be relleased to the biosphere are regulated strictly, a thorough knowledge 
of the quantities of gaseous fission products released at various storage temperatures is needed to assist in making the design decisions. An experiment to measure fission gas $\left({ }^{85} \mathrm{Kr}\right.$ and $\left.{ }^{3} \mathrm{H}\right)$ releases during storage of an irradiated fuel element was started on Jan. 27, 1975, and terminated June 30, 1977. Studies were made at ambient temperature $\left(30^{\circ} \mathrm{C}\right)$, and at $100,150,200$, and $300^{\circ} \mathrm{C}$. Details of the experiment are presented below.

\section{FUEL DESCRIPTION AND IRRADIATION DATA}

RTF- - -5, whirh was rhnsen for these tests; is a rylindriral graphite body about $7.6 \mathrm{~cm}$ diam by $38.1 \mathrm{~cm}$ long containing a central hole and eight smaller holes arranged like a telephone dial. The eight smaller holes contain the fuel; seven of the holes still had the original loading, whereas the fuel had been removed from the eighth. This particular body was loaded with mixtures of BISO-coated $(4 \mathrm{Th} / \mathrm{U}) \mathrm{O}_{2}$ particles, BISO-coated $\mathrm{ThC}_{2}$ particles, and particles of graphite flour. The three particles were loaded concurrently from three vibrating V-trough feeders. The entire body was vibrated after filling to settle the bed, and additional graphite flour was added to fill the voids. The beds were sealed in place by adding $2 \mathrm{~cm}^{3}$ of methyl ethyl ketone and $10 \%$ polystyrene. (The fueled bodies were loaded into Peach Bottom fuel elements. Details of the fabrication and irradiation of the coated particles and the recycle test elements are reported elsewhere. ${ }^{1,2}$ )

As stated above, fuel from one of the channels had been removed for PIE. Additionally, three graphite components - the spine, a fuel hole plug, and a top sample hole plug - had also been removed. The assembled weight of body RTE-2-5 is reported ${ }^{2}$ as $2531.5 \mathrm{~g}$; if the weights of missing fuel and components are deducted, the weight as received should have been $2091.8 \mathrm{~g}$. (A total of $590.2 \mathrm{~g}$ of coated particles is contained in this gross weight.)

\section{EXPERIMENTAL EQUIPMENT AND PROCEDURE}

The experimental apparatus consisted of a sealed, purged, heated container to hold the fuel element. The container was made of an 
insulated 4-in. sched. 40 stainless steel pipe 18 in. long and flanged at one end with an O-ring seal. A Calrod unit supplied heat for the tests at the elevated temperatures (Fig. 1).

Monitoring and collection of the off-gases for subsequent analyses were performed using the off-gas instrumentation from head-end studies. ${ }^{3}$ The off-gas system consisted of a $\mathrm{CO}$ analyzer, a $\mathrm{CO}_{2}$ analyzer, a multichannel analyzer gamma spectrometer, a heated CuO bed (to oxidize any HT to HTO), molecular sieve traps (for HTO remova1), a wet-test meter, and an inflatable gas collection bag. The $\mathrm{CO}$ and $\mathrm{CO}_{2}$ analyzers were in the system only for the $300^{\circ} \mathrm{C}$ test. An absolute filter was in the line for the test at $100^{\circ} \mathrm{C}$.

The primary goal of the experiment was to monitor the releases of ${ }^{85} \mathrm{Kr}$ and ${ }^{3} \mathrm{H}$ at various storage temperatures. Since the in-line gammadetector does not yield absolute values for krypton concentrations, replicate gas samples were taken from the collapsible gas collection bag after each collection interval and counted in a 2-in.-well NaI detector. The sweep gas was humidified to provide isotopic dilution for the ${ }^{3} \mathrm{H}$, and the resultant HTO was adsorbed on molecular sieves (Type 4A). The HTO was recovered by refluxing the sieves for $4 \mathrm{hr}$ in $50 \mathrm{ml}$ of $\mathrm{H}_{2} \mathrm{O}$. The leach solution was analyzed for tritium content by beta liquid scintillation.

The element was purged with moist air continuously at the beginning of each test until a reasonably stable release rate was observed. Once this rate was attained, the unit was sealed at temperature and purged once weekly for a total purge volume of at least ten volume changes of the test chamber. The duration of the experiment at ambient temperature $\left(\sim 30^{\circ} \mathrm{C}\right), 100,150,200$, and $300^{\circ} \mathrm{C}$ was $70,78,108,554$, and 66 days, respectively. The extended test at $200^{\circ} \mathrm{C}$ (554 days) was performed to observe any long-term changes in the apparently stable release rate.

The experimental release values must be generalized if these values are to be used in the design of a storage facility. The total inventories of ${ }^{85} \mathrm{Kr}$ and ${ }^{3} \mathrm{H}$ in $\mathrm{RTE}-2-5$ have been estimated by analogy to 


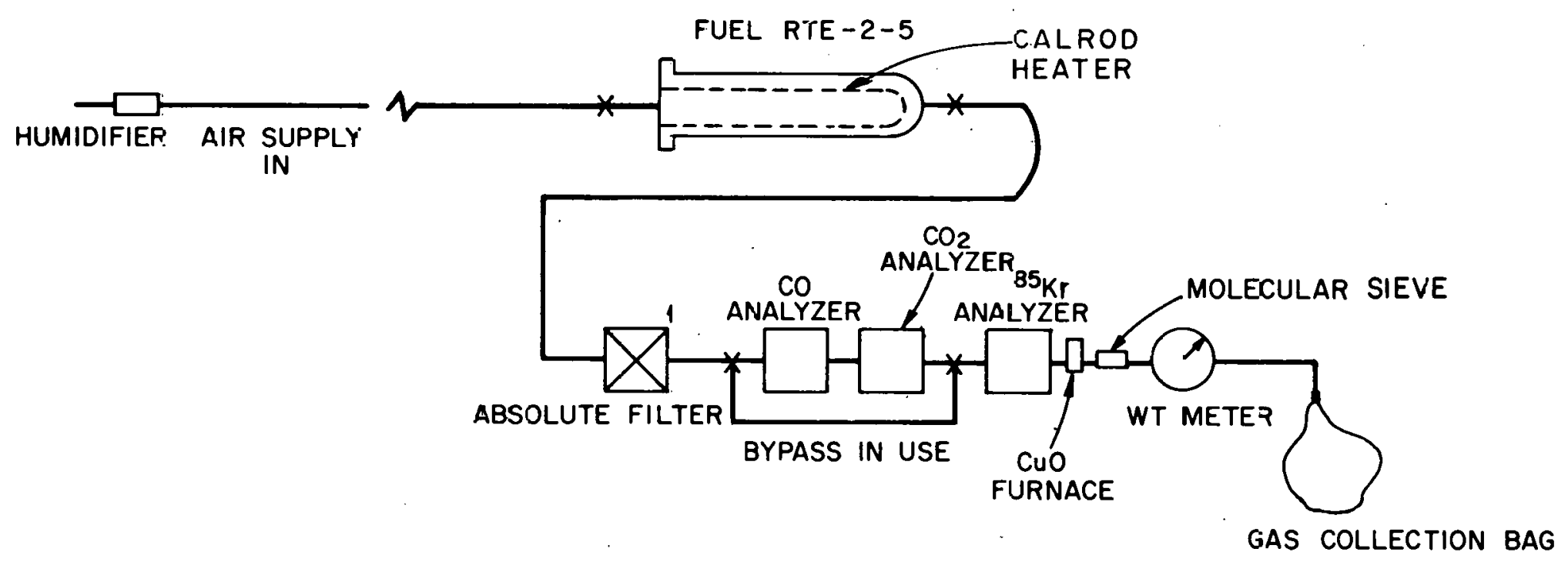

1- NOT IN LINE AT AMBIENT TEMPERATIJRE

Fig. 1. Experimental arrangement for storage experiment RTE-2-5. 
fuel body RTE-2-3 of the same fuel element with the assistance of the ORIGEN code. ${ }^{4}$ About $0.38 \mathrm{Ci}$ of ${ }^{85} \mathrm{Kr}$ per fuel channel was predicted for RTE-2-3. We directly measured $0.31 \mathrm{Ci}$ of ${ }^{85} \mathrm{Kr}$ (about $80 \%$ of the predicted amount) in head-end experiments involving fuel channel RTE$2-3-2 .^{5}$ The neutron flux at the RTE-2-5 position was about $75 \%$ of the flux at RTE-2-3; however, RTE-2-5 contained more uranium and thorium than RTE-2-3. By adjusting the ORIGEN yield of ${ }^{85} \mathrm{Kr}$ for RTE-2-3 by simple factors, we have estimated ${ }^{85} \mathrm{Kr}$ and ${ }^{3} \mathrm{H}$ inventories of $2.6 \mathrm{Ci}$ and $56 \mathrm{mCi}$, respectively, in $\mathrm{RTE}-2-5$.

\section{EXPERIMENTAL RESULTS}

Releases of krypton and tritium during storage. The average daily releases for each temperature are shown in Figs. 2-6. The experimental values are presented in Tables A-1 through A-10 in the Appendix. Each change in temperature, except at $300^{\circ} \mathrm{C}$, resulted in a sharp increase in the daily release rate, which then decreased asymptotically with time. The release rates at $300^{\circ} \mathrm{C}$ did not decrease significantly over the period of the test (66 days).

To provide a comparison of the changes in release rates with temperature, the values between about 30 and 100 days into the test were averaged. A few obviously divergent values were omitted from the averages (see Tables $\mathrm{A}-1-\mathrm{A}-10$ ). These averages, and the rariges calculated using Student's $t$ method for the $95 \%$ confidence interval, are presented in Table 1 . An increase was observed in the average release rates between day 30 and day 100 with increasing temperature.

An Arrhenius plot of these data indicates that there is some regularity of behavior (Fig. 7). The solid lines fit equations as shown in (1) and (2) below:

$$
\begin{aligned}
& \text { for }{ }^{85} \mathrm{Kr}, \mathrm{k}=3.937 \times 10^{6} \mathrm{e}^{-7820 / \mathrm{RT}} \text {; } \\
& \text { for }{ }^{3} \mathrm{H}, \mathrm{k}=1.042 \times 10^{6} \mathrm{e}^{-1.2,400 / \mathrm{RT}} \text {; }
\end{aligned}
$$

where $k$ is the rate of release in $\mu \mathrm{Ci}$ /day, $\mathrm{R}$ is the ideal gas constant ( $1.987 \mathrm{cal} / \mathrm{mule} \cdot \mathrm{K}$ ), and $\mathrm{T}$ is the temperature in $\mathrm{K}$.

The data points and ranges (95\% confidence interval, by Student's $t)$ are also presented. It is clear that the data at ambient temperature $\left(\sim 30^{\circ} \mathrm{C}\right)$ lie well above the predictions. Several hypotheses for this bchavior may be advancer. One is that the fresh fuel had a "surplus" 
Table 1. Releases of ${ }^{85} \mathrm{Kr}$ and ${ }^{3} \mathrm{H}$ at various temperatures

\begin{tabular}{|c|c|c|c|c|c|c|c|c|c|}
\hline \multirow{4}{*}{$\begin{array}{c}\text { Temperature } \\
\left({ }^{\circ} \mathrm{C}\right)\end{array}$} & \multirow{4}{*}{$\begin{array}{l}\text { Dates } \\
\text { from/to }\end{array}$} & \multirow{2}{*}{\multicolumn{3}{|c|}{${ }^{85} \mathrm{Kr}$}} & \multicolumn{5}{|c|}{$3_{H}$} \\
\hline & & & & & \multirow{3}{*}{$\begin{array}{l}\text { EmCi from } \\
\text { start of } \\
\text { experiment }\end{array}$} & \multirow{2}{*}{\multicolumn{2}{|c|}{$\begin{array}{l}\text { Release rate } \\
(\mu \mathrm{C} \mathbf{i} / \mathrm{day}) \\
\end{array}$}} & \multirow{3}{*}{$\begin{array}{c}\text { Total } \\
\mu \mathrm{Ci} f \\
\text { in period } \\
\end{array}$} & \multirow{3}{*}{$\begin{array}{c}\qquad \mu \mathrm{Ci} \\
\text { from start of } \\
\text { experiment }\end{array}$} \\
\hline & & \multicolumn{2}{|c|}{$\begin{array}{c}\text { Release rate } \\
(\mu a i / \text { day })\end{array}$} & \multirow{2}{*}{$\begin{array}{l}\text { Total } \\
\text { Ci in } \\
\text { period }\end{array}$} & & & & & \\
\hline & & Initial & End & & & Initial & End & & \\
\hline Ambient & $1-2 \bar{i}-75 / 4-c-75$ & 900 ] & $60 \pm 16$ & 16 & 16 & 3.0 & $0.024 \pm 0.007$ & 8.46 & 8.46 \\
\hline 100 & $4-4-75 / 6-20-75$ & 6001 & $103 \pm 51$ & 67 & 83 & 0.3 & $0.045 \pm 0.039$ & 8.53 & 17 \\
\hline 150 & $5-20-75 / 10-17-75$ & 1001 & $394 \pm 107$ & 40 & 123 & 0.3 & $0.376 \pm 0.218$ & 93.5 & 111 \\
\hline 200 & $10-17-75 / 4-20-77$ & 4000 & $844 \pm 476$ & 202 & 325 & 1.2 & $0.749 \pm 0.388$ & 701 & 812 \\
\hline 300 & $\dot{4}-27 \cdot 77 / 6-30-77$ & 5000 & $4095 \pm 82$ & 1606 & 44.2 & $19.3 \pm 0.7$ & & 1307 & 2119 \\
\hline
\end{tabular}

${ }^{a}$ Average of values between $\sim 30$ and $\sim 100$ days with $95 \%$ rarge (by Student's $t$ ). 
ONML OWG 77.1827 A

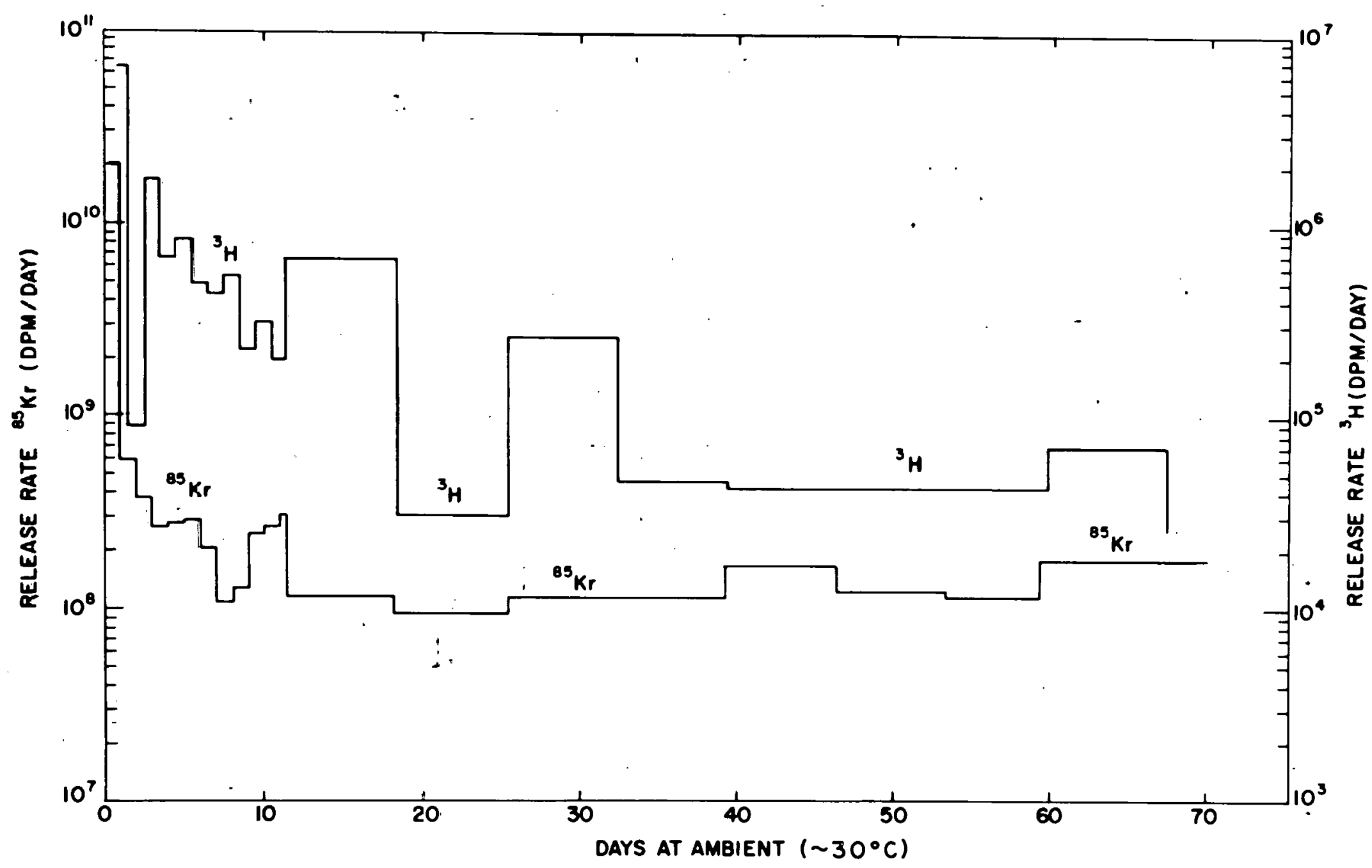

Fig. 2. Release rates for ${ }^{85} \mathrm{Kr}$ and ${ }^{3} \mathrm{H}$ at ambient temperature $\left(30^{\circ} \mathrm{C}\right)$. 
ORWL OWG $\pi-1828$

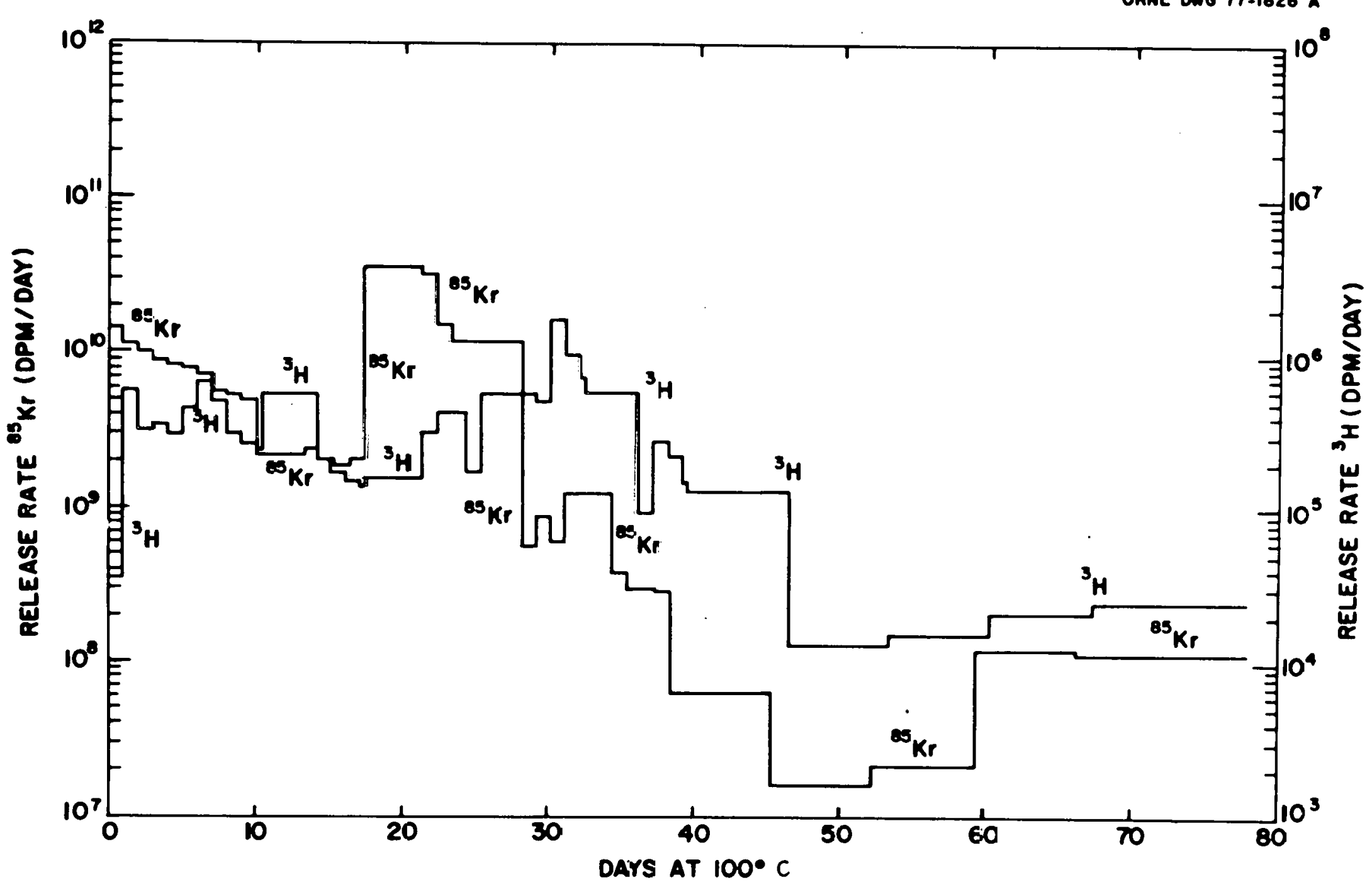

Fig. 3. Release rates for ${ }^{85} \mathrm{Kr}$ and ${ }^{3} \mathrm{H}$ at $100^{\circ} \mathrm{C}$. 


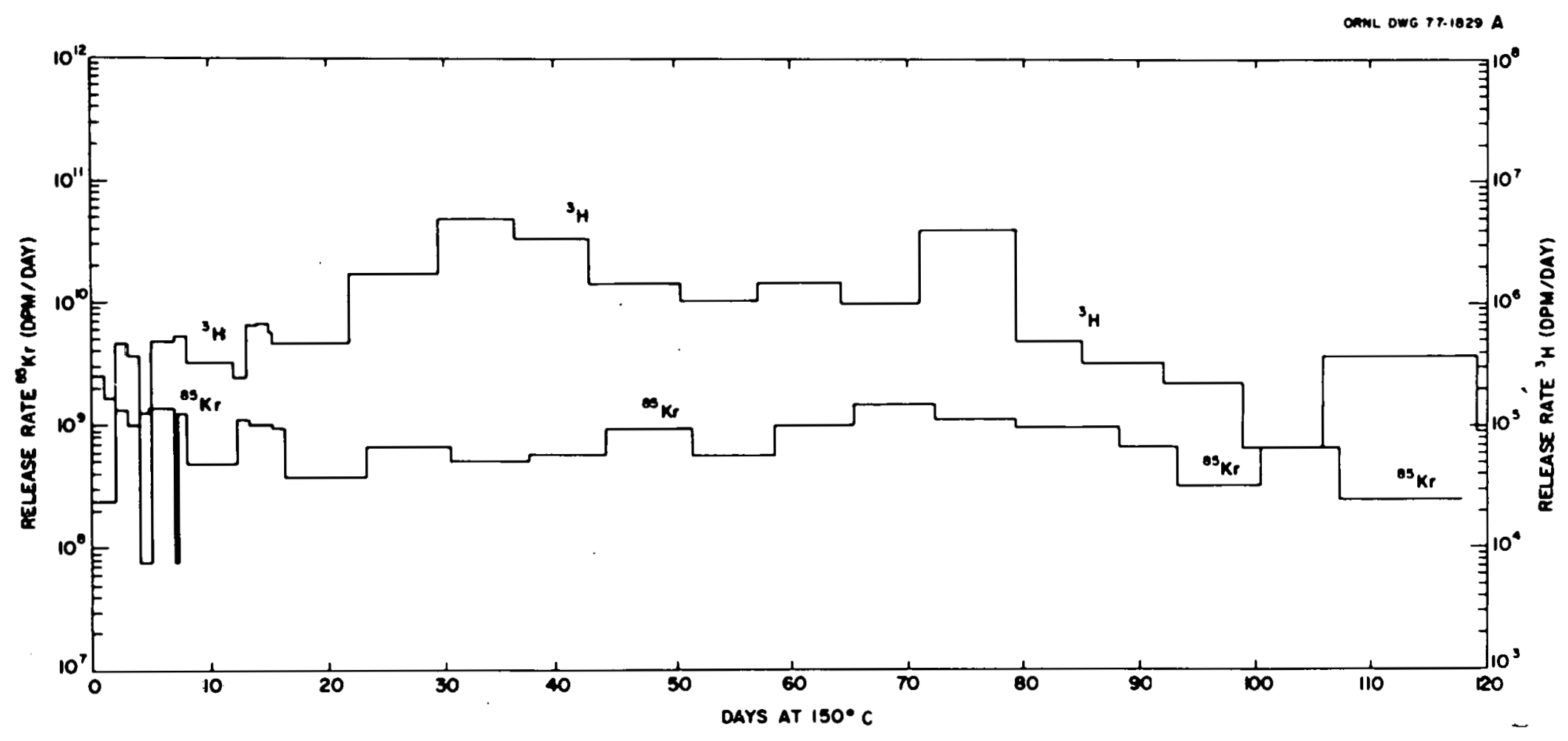

Fig. 4. Release rates for ${ }^{85} \mathrm{Kr}$ and ${ }^{3} \mathrm{H}$ at $150^{\circ} \mathrm{C}$. 
ORNL OWG $77-1830 R 2$
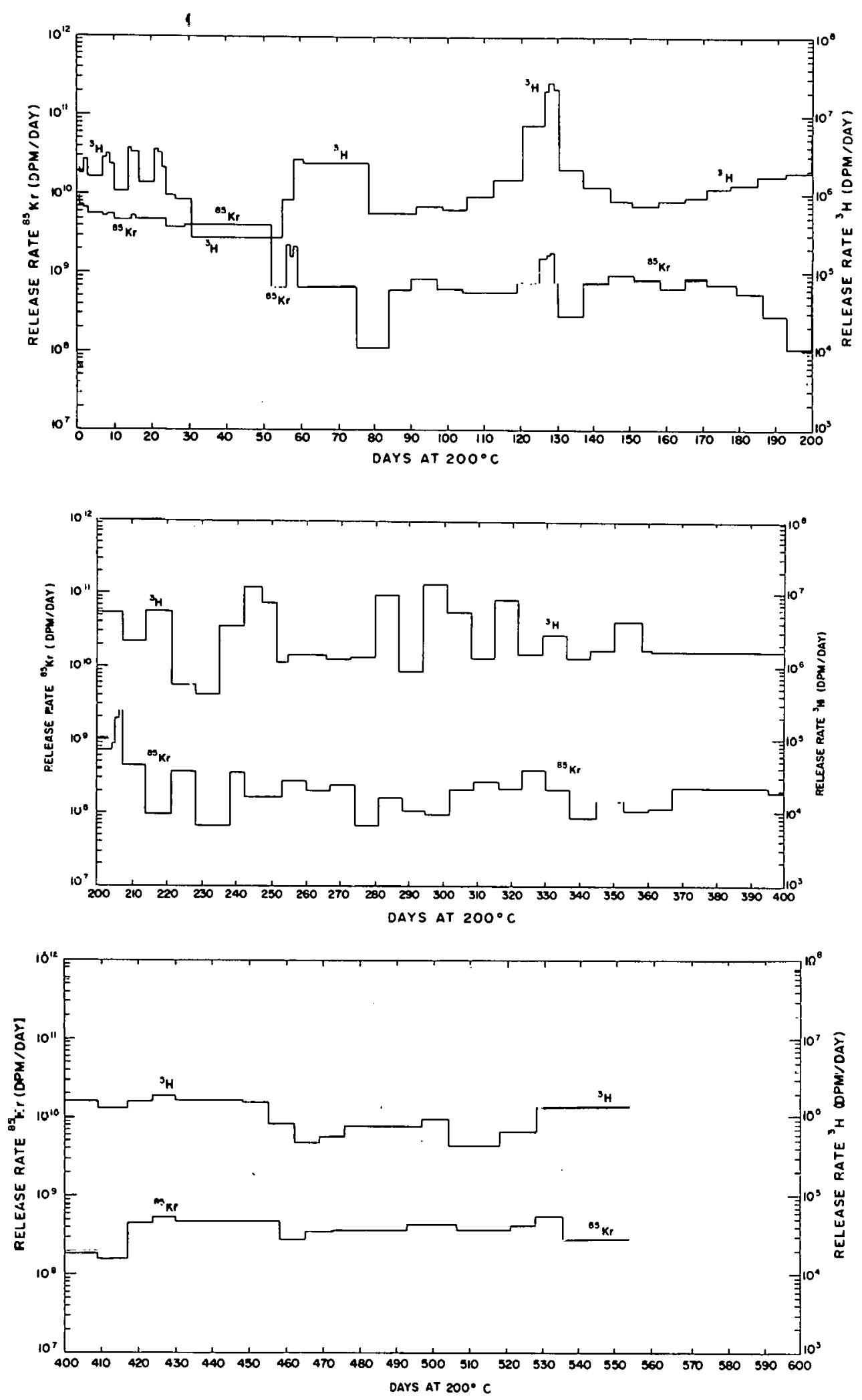

Fig. 5. Release rates for ${ }^{85} \mathrm{Kr}$ and ${ }^{3} \mathrm{H}$ at $200^{\circ} \mathrm{C}$. 
ORNL OWG 77-18318

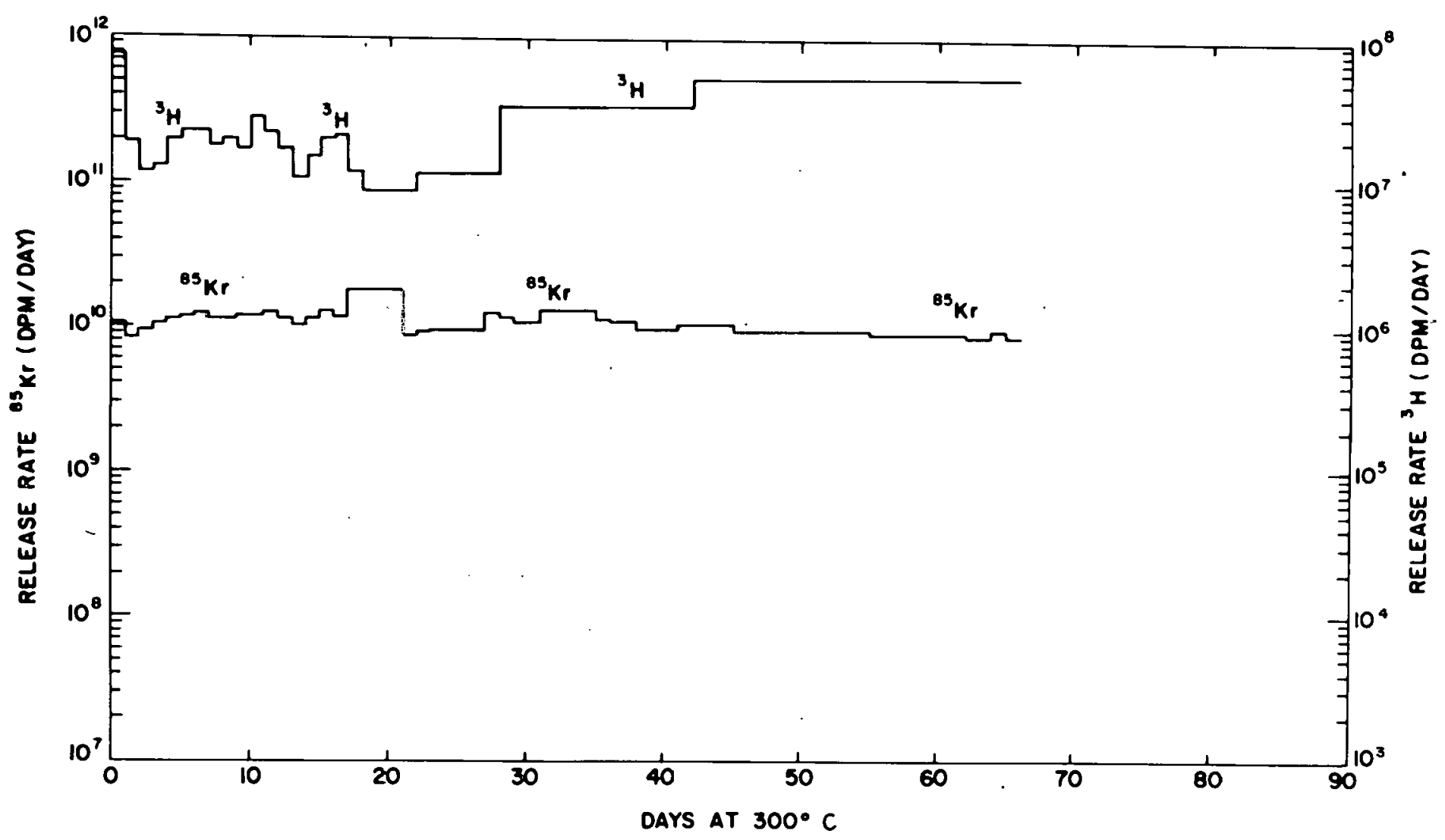

Fig. 6. Release rates for ${ }^{85} \mathrm{Kr}$ and ${ }^{3} \mathrm{H}$ at $300^{\circ} \mathrm{C}$. 


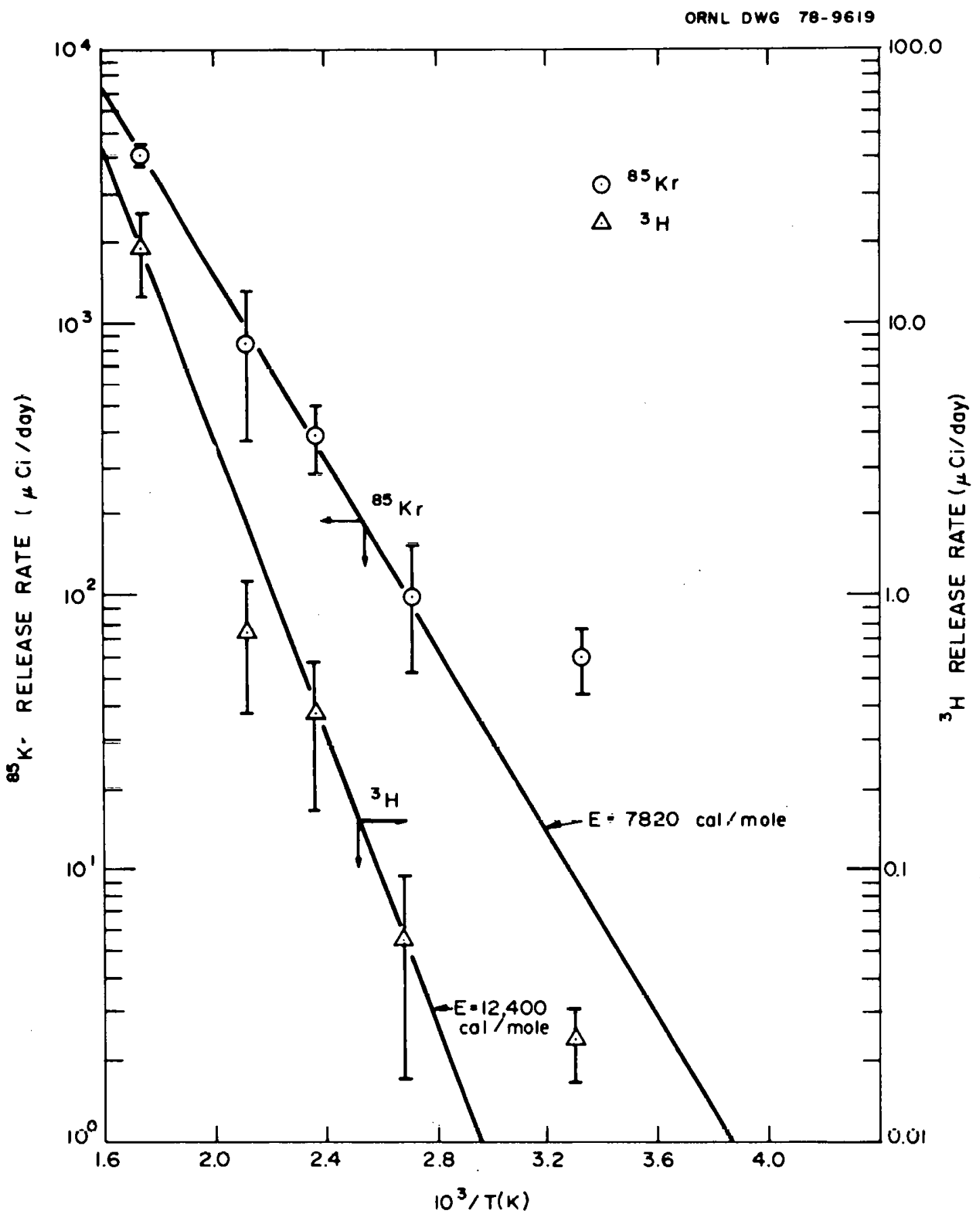

Fig. 7. Arrhenius plot of release rates during storage at various temperatures. 
inventory in its pores, which was released rather easily. This hypothesis is given some credence by the very high release rates $\left(3885 \pm 941 \mu \mathrm{Ci}\right.$ of ${ }^{85} \mathrm{Kr}$ per day) seen at the start of the $100^{\circ} \mathrm{C}$ series. Thus, perhaps the experiment was not run long enough under ambient conditions to measure the release mechanism seen in the later tests.

The other data, however, are in relatively good agreement with the results predicted by the Arrhenius equation. For interpolation, the release rates predicted by the Arrhenius correlation are presented on a semilogarithmic plot of release rates vs temperature (Fig. 8).

The krypton release rate increased by almost a factor of 70 , while the tritium release rate increased about a factor of 800 over the temperature range 30 to $300^{\circ} \mathrm{C}$.

In the test of longest duration $\left(200^{\circ} \mathrm{C}\right)$, the release rates continued to decrease slowly until the temperature was changed. The final average values for ${ }^{85} \mathrm{Kr}$ and ${ }^{3} \mathrm{H}$ (after 554 days at $200^{\circ} \mathrm{C}$ ) were $175.8 \pm 23.3 \mu \mathrm{Ci} / \mathrm{day}$ and $0.460 \pm 0.130 \mu \mathrm{Ci} /$ day, respectively. Overall, about $24 \%$ of the ${ }^{85} \mathrm{Kr}$ and about $4 \%$ of the tritium were evolved over the two and one-half years of testing.

Release of other fission products during storage. An absolute filter (Pall Corporation, Cortland, N.Y., Part No. DEA 3001URA) was placed in the off $\rightarrow$ gas line for the test at $100^{\circ} \mathrm{C}$. The principal gamma emitters found on the filter at the end of the test are shown in Table 2. Their levels of activity ranged from about $0.1 \mu \mathrm{Ci}$ for ${ }^{125} \mathrm{Sb}$ to about $0.75 \mu \mathrm{Ci}$ for ${ }^{144} \mathrm{Ce}$. These results can be taken as maximum values since there is a possibility that some of the activity is a result of incell contamination, even though a diligent effort was made to ensure that the exterior of the filter body was free from contamination.

The container for the fuel body was decontaminated (externally) and gamma scanned at the end of the experiment. These results are shown in Table 3 . The values ranged from about 7 HCi for ${ }^{125}$ Sb to about $573 \mu \mathrm{C} i$ for ${ }^{144} \mathrm{Ce}$. As stated above, these results may be taken as maximum values. One should note that both fertile and fissile particles are BISO-coated, and a degree of migration of fission products through these coatings is not uncommon. 
ORNL DWG $78-9618$

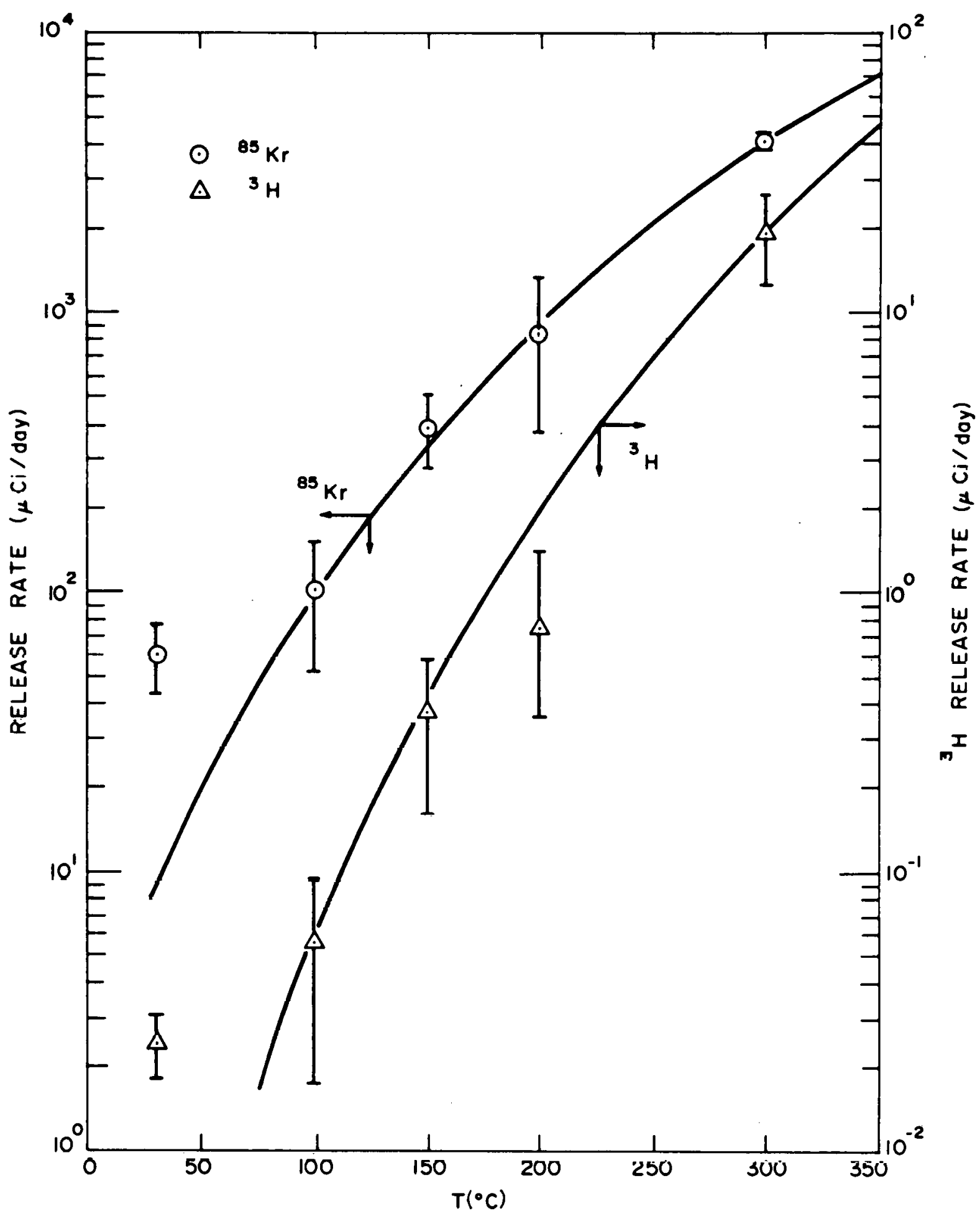

Fig. 8. Releases of ${ }^{85} \mathrm{Kr}$ and ${ }^{3} \mathrm{H}$ from stored HTGR fuel at various temperatures ( 30 to 100 days at temperature). 
Table 2. Amounts of activity found on the absolute filter in the off-gas line of the storage test at $100^{\circ} \mathrm{C}$

\begin{tabular}{lcc}
\hline Nuclide & $\begin{array}{c}\text { Amount found } \\
(\mathrm{dpm})\end{array}$ & $\begin{array}{c}\text { Apparent concentration } \\
\left(\mu \mathrm{Ci} / \ell^{\mathrm{a}}\right)\end{array}$ \\
\hline${ }^{95} \mathrm{Zr-}{ }^{95} \mathrm{Nb}$ & Trace & - \\
${ }^{106} \mathrm{Ru}$ & $2.34 \times 10^{5}$ & $5.4 \times 10^{-4}$ \\
${ }^{125} \mathrm{Sb}$ & $2.30 \times 10^{5}$ & $5.3 \times 10^{-5}$ \\
${ }^{134} \mathrm{Cs}$ & $3.48 \times 10^{5}$ & $8.0 \times 10^{-5}$ \\
$137 \mathrm{Cs}$ & $4.78 \times 10^{5}$ & $1.1 \times 10^{-4}$ \\
$144 \mathrm{Ce}$ & $1.67 \times 10^{6}$ & $3.8 \times 10^{-4}$ \\
\hline
\end{tabular}

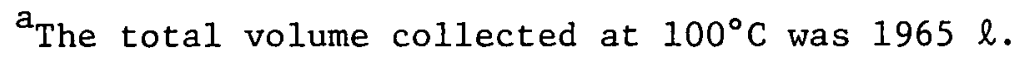

Table 3. Amounts of residual activity found in the fuel body container by gamma scanning

\begin{tabular}{lc}
\hline Nuclide & Amount found $(\mathrm{dpm})$ \\
\hline${ }^{106} \mathrm{Ru}$ & $1.78 \times 10^{7}$ \\
${ }^{125} \mathrm{Sb}$ & $5.75 \times 10^{6}$ \\
$13{ }^{4} \mathrm{Cs}$ & $1.15 \times 10^{8}$ \\
${ }^{137} \mathrm{Cs}$ & $3.16 \times 10^{8}$ \\
$144 \mathrm{Ce}$ & $3.65 \times 10^{7}$ \\
\hline
\end{tabular}


The container for the fuel body was rinsed with demineralized water to remove any particulates adhering to the inner surface. The container was then washed with basic and acidic solutions. The basic solution contained (per liter) $1.52 \mathrm{~g}$ of $\mathrm{NaOH}, 0.5 \mathrm{~g}$ of $\mathrm{KI}$, and $1.4 \mathrm{~g}$ of $\mathrm{NaHSO}_{3}$ to remove ${ }^{129} \mathrm{I}$. The acidic solution, $8 \mathrm{M} \mathrm{HNO}_{3}$, was used to leach other fission products. The principal gamma emitters contained in these solutions are shown in Table 4. The amounts reported in this table are within about a factor of 2 of those reported in Table 3, representing reasonable consistency for measurements of this type.

Reactions between the air purge gas and the fuel element stored at $300^{\circ} \mathrm{C}$. The carbon monoxide and carbon dioxide analyzers were in-line for the test at $300^{\circ} \mathrm{C}$ to observe any possible oxidation. The $\mathrm{CO}_{2}$ analyzer indicated that the purge gas contained about $1 \% \mathrm{CO}_{2}$. Samples taken for analysis by gas chromatography indicated an average $\mathrm{CO}_{2}$ concentration of $1.12 \%$ in the off-gas. If we assume that this value is an average concentration for the entire test at $300^{\circ} \mathrm{C}$, the observed weight loss should be $31.7 \mathrm{~g}$. The original weight (as received) was not available. The fuel body weighed $12.9 \mathrm{~g}$ less than the calculated weight of $2091.8 \mathrm{~g}$ at the end of the experiment. Visual inspection of the body revealed evidence of a slight amount of erosion on the inlet side of the purge line. We conclude that there was some attack of the fuel body at $300^{\circ} \mathrm{C}$ by the purge air.

\section{CONCLUSIONS}

Spent fuel elements must be stored in the near future. Any offgases from such a storage facility will need to meet the requirements of existing regulations for releases of radioactive species. The concentrations of gaseous contaminants expected to be released at the storage temperature can be estimated from these data, and will have to be considered in the design of the facility. The loss of up to $22 \%$ of the ${ }^{85} \mathrm{Kr}$ and $4 \%$ of the tritium inventories of the spent fuel elements may require containment of the activity. Releases of particulates and other fission products do not appear to present unusual problems. Design trade-offs between costs of fuel element containment and any off-gas cleanup methods will need to be performed. 
Table 4. Amounts of activity found in fuel body container wash solutions

\begin{tabular}{|c|c|c|c|c|}
\hline \multirow{2}{*}{$\begin{array}{c}\text { Isotope } \\
\text { (dpm tota1) }\end{array}$} & \multicolumn{4}{|c|}{ Wash solutions } \\
\hline & Water & Basic & Acid & $\sum \mathrm{dpm}$ \\
\hline${ }^{106} \mathrm{Ru}$ & $<3.33 \times 10^{6}$ & $<2.22 \times 10^{5}$ & $<1.11 \times 10^{7}$ & $<1.5 \times 10^{7}$ \\
\hline${ }^{125} \mathrm{Sb}$ & $<2.22 \times 10^{6}$ & $<1.11 \times 10^{5}$ & $<3.33 \times 10^{6}$ & $<5.7 \times 10^{6}$ \\
\hline${ }^{134} \mathrm{Cs}$ & $1.67 \times 10^{8}$ & $1.01 \times 10^{7}$ & $7.35 \times 10^{7}$ & $2.51 \times 10^{8}$ \\
\hline${ }^{137} \mathrm{Cs}$ & $3.77 \times 10^{8}$ & $2.33 \times 10^{7}$ & $1.75 \times 10^{8}$ & $5.74 \times 10^{8}$ \\
\hline${ }^{144} \mathrm{Ce}$ & $<2.22 \times 10^{7}$ & $2.55 \times 10^{6}$ & $4.91 \times 10^{7}$ & $<7.4 \times 10^{7}$ \\
\hline${ }^{154} \mathrm{Eu}$ & $<2.22 \times 10^{6}$ & $<3.33 \times 10^{5}$ & $4.52 \times 10^{6}$ & $<7.1 \times 10^{6}$ \\
\hline${ }^{129} \mathrm{I}, \mu \mathrm{g}$ & - & 1.94 & - & 1.94 \\
\hline
\end{tabular}




\section{REFERENCES}

1. R. P. Morisette and K. P. Steward, Recycle Test Element Program Design, Fabrication, and Assembly, GA-10109 (September 1971).

2. E. I. Long, R. B. Fitts, and F. J. Homan, Fabrication of ORNL Fuel Irradiated in the Peach Bottom Reactor and Postirradiation Examination of Recycle Test Elements 7 and 4, ORNL/TM-4477 (September 1974).

3. C. L. Fitzgerald, V. C. A. Vaughen, K. J. Notz, and R. S. Lowrie, Head-end Reprocessing Studies with Irradiated HTGR-Type Fuels, Studies with RTE-7: TRISO UC2-TRISO ThC2, ORNL-5090 (November 1975).

4. M. J. Bell, ORIGEN, The ORNL Isotope Generation and Depletion Code, ORNL-4628 (May 1973).

5. A. L. Lotts and P. R. Kasten, Gas-Cooled Reactor Programs - Thorium Utilization Program Progress Report - January 1, 1974-June 30, 1975, ORNL-5128 (May 1976). 
$-19-$

7. APPENDIX: TABULATED RESULTS OF ${ }^{85} \mathrm{Kr}$ AND ${ }^{3} \mathrm{H}$ RELEASES FOR STORAGE EXPERTMENT RTE-2-3-5 
Table A-1. Release rate for ${ }^{85} \mathrm{Kr}$ at ambient temperature $\left(\sim 30^{\circ} \mathrm{C}\right)$

\begin{tabular}{cccccc}
\hline Accumulated days & $\begin{array}{c}\text { Gas bag vol. } \\
\text { (liters) }\end{array}$ & ${ }^{\mathrm{Kr}}(\mathrm{dpm} / \mathrm{day})$ & ${ }^{85} \mathrm{Kr}(\mu \mathrm{Ci} /$ day $)$ & $\begin{array}{c}\text { Accumulated } \\
85 \mathrm{Kr}(\mathrm{mCi})\end{array}$ \\
\hline 1 & 57 & $2.04 \times 10^{10}$ & $9.1 .8 \times 10^{3}$ & 9.18 \\
2 & 58.5 & $5.83 \times 10^{8}$ & $2.63 \times 10^{2}$ & 9.43 \\
3 & 55.8 & $3.77 \times 10^{8}$ & $1.7 \times 10^{2}$ & 9.61 \\
4 & 56.5 & $2.65 \times 10^{8}$ & $1.19 \times 10^{2}$ & 9.73 \\
5 & 61.4 & $2.79 \times 10^{8}$ & $1.26 \times 10^{2}$ & 9.86 \\
6 & 63.0 & $2.82 \times 10^{8}$ & $1.27 \times 10^{2}$ & 9.98 \\
7 & 62.0 & $2.01 \times 10^{8}$ & $1.27 \times 10^{2}$ & 10.11 \\
8 & 61.5 & $1.87 \times 10^{8}$ & $8.41 \times 10^{1}$ & 10.19 \\
9 & 60.0 & $2.9 \times 10^{8}$ & $1.31 \times 10^{2}$ & 10.32 \\
10 & 58.4 & $2.41 \times 10^{8}$ & $1.09 \times 10^{2}$ & 10.43 \\
11 & 57.1 & $2.63 \times 10^{8}$ & $1.18 \times 10^{2}$ & 10.55 \\
12 & 18.8 & $3.03 \times 10^{8}$ & $4.50 \times 10^{1 \mathrm{a}}$ & 10.59 \\
19 & 36.0 & $1.17 \times 10^{8}$ & $5.26 \times 10^{1 \mathrm{a}}$ & 10.95 \\
25 & 36.0 & $9.39 \times 10^{7}$ & $4.23 \times 10^{1 \mathrm{a}}$ & 11.25 \\
32 & 37.7 & $1.02 \times 10^{8}$ & $4.61 \times 10^{1 \mathrm{a}}$ & 11.58 \\
39 & 38.5 & $1.13 \times 10^{8}$ & $5.09 \times 10^{1 \mathrm{a}}$ & 11.93 \\
46 & 38.6 & $6.39 \times 10^{8}$ & $2.88 \times 10^{2}$ & 13.95 \\
53 & 37.7 & $2.06 \times 10^{8}$ & $9.3 \times 10^{1 \mathrm{a}}$ & 14.60 \\
59 & 35.5 & $1.53 \times 10^{8}$ & $6.88 \times 10^{10}$ & 15.01 \\
70 & 36.0 & $1.80 \times 10^{8}$ & $8.12 \times 10^{1 \mathrm{a}}$ & 15.66 \\
\hline
\end{tabular}

${ }^{a}$ Values used to determine average and range, $\bar{x}=60.0 \pm 15.8$. 
Table A-2. Release rate for ${ }^{85} \mathrm{Kr}$ at $100^{\circ} \mathrm{C}$

\begin{tabular}{|c|c|c|c|c|}
\hline Accumulated days & $\begin{array}{c}\text { Gas bag vol. } \\
\text { (liters) }\end{array}$ & ${ }^{85} \mathrm{Kr}$ (dpm/day) & $85_{\mathrm{Kr}}(\mu \mathrm{Ci} / \mathrm{day})$ & $\begin{array}{l}\text { Accumulated } \\
85 \mathrm{Kr} \text { (mCi) }\end{array}$ \\
\hline 1 & 61.8 & $1.44 \times 10^{10}$ & $6.5 \times 10^{3}$ & 6.51 \\
\hline 2 & 62.8 & $1.13 \times 10^{10}$ & $5.08 \times 10^{3}$ & 11.60 \\
\hline 3 & 68.9 & $1.06 \times 10^{10}$ & $4.76 \times 10^{3}$ & 16.36 \\
\hline 4 & 58.5 & $9.19 \times 10^{9}$ & $4.14 \times 10^{3}$ & 20.5 \\
\hline 5 & 67.0 & $8.68 \times 10^{9}$ & $3.91 \times 10^{3}$ & 24.41 \\
\hline 6 & 68.0 & $8.32 \times 10^{9}$ & $3.75 \times 10^{3}$ & 28.16 \\
\hline 7 & 68.7 & $7.34 \times 10^{9}$ & $3.31 \times 10^{3}$ & 31.46 \\
\hline 8 & 62.3 & $5.84 \times 10^{9}$ & $2.63 \times 10^{3}$ & 34.09 \\
\hline 9 & 71.0 & $5.58 \times 10^{9}$ & $2.51 \times 10^{3}$ & 36.61 \\
\hline 10 & 73.0 & $5.0 \times 10^{9}$ & $2.25 \times 10^{3}$ & 38.86 \\
\hline 13.33 & 39.3 & $2.25 \times 10^{9}$ & $1.01 \times 10^{3}$ & 39.87 \\
\hline 14.33 & 63.6 & $2.38 \times 10^{9}$ & $1.07 \times 10^{3}$ & 40.95 \\
\hline 15.33 & 66.7 & $2.13 \times 10^{9}$ & $9.6 \times 10^{2}$ & 41.91 \\
\hline 16.33 & 68.2 & $1.94 \times 10^{9}$ & $8.73 \times 10^{2}$ & 42.78 \\
\hline 17.33 & 69.9 & $2.09 \times 10^{9}$ & $9.39 \times 10^{2}$ & 43.72 \\
\hline 21.33 & 60.0 & $3.64 \times 10^{10}$ & $1.64 \times 10^{4}$ & 60.12 \\
\hline 22.33 & 73.0 & $3.30 \times 10^{9}$ & $1.49 \times 10^{3}$ & 61.61 \\
\hline 23.33 & 61.0 & $1.64 \times 10^{9}$ & $7.37 \times 10^{2}$ & 62.34 \\
\hline 24.33 & 66.3 & $1.25 \times 10^{9}$ & $5.61 \times 10^{2}$ & 62.80 \\
\hline 28.0 & 68.0 & $1.28 \times 10^{9}$ & $5.76 \times 10^{2}$ & 63.38 \\
\hline 29.0 & 59.6 & $5.95 \times 10^{8}$ & $2.68 \times 10^{2}$ & 63.65 \\
\hline 30.0 & 62.0 & $9.06 \times 10^{8}$ & $4.08 \times 10^{2}$ & 64.06 \\
\hline 31.0 & 70.5 & $6.20 \times 10^{8}$ & $2.79 \times 10^{2}$ & 64.34 \\
\hline 34.33 & 40.1 & $1.33 \times 10^{9}$ & $5.97 \times 10^{2}$ & 64.93 \\
\hline 35.33 & 63.8 & $3.83 \times 10^{8}$ & $1.73 \times 10^{2 a}$ & 65.11 \\
\hline 36.33 & 63.2 & $3.13 \times 10^{8}$ & $1.41 \times 10^{2 \mathrm{a}}$ & 65.25 \\
\hline 37.33 & 63.0 & $2.99 \times 10^{8}$ & $1.35 \times 10^{2 a}$ & 65.38 \\
\hline 38.33 & 60.8 & $2.91 \times 10^{8}$ & $1.31 \times 10^{2 a}$ & $65: 51$ \\
\hline 45.33 & 41.2 & $6.61 \times 10^{7}$ & $2.98 \times 10^{1 \mathrm{a}}$ & 65.72 \\
\hline 52.33 & 35.8 & $1.6 \times 10^{\prime}$ & $7.2 \times 10^{\circ}$ & 65.77 \\
\hline 59.33 & 36.0 & $2.15 \times 10^{7}$ & $9.69 \times 10^{\circ}$ & 65.84 \\
\hline 66.33 & 36.6 & $1.27 \times 10^{8}$ & $5.72 \times 10^{1 a}$ & 66.24 \\
\hline 78 & 35.2 & $1.18 \times 10^{8}$ & $5.34 \times 10^{1 \mathrm{a}}$ & 66.61 \\
\hline
\end{tabular}

avalues used to determine average, $\bar{x}=102.9 \pm 50.8 \%$. 
Table A-3. Release rate for ${ }^{85} \mathrm{Kr}$ at $150^{\circ} \mathrm{C}$

\begin{tabular}{|c|c|c|c|c|}
\hline Accumulated days & $\begin{array}{c}\text { Gas bag vol. } \\
\text { (1iters) }\end{array}$ & $85_{\mathrm{Kr}}(\mathrm{dpm} /$ day $)$ & ${ }^{85} \mathrm{Kr}(\mu \mathrm{Ci} /$ day $)$ & $\begin{array}{l}\text { Accumulated } \\
85_{\mathrm{Kr} \quad(\mathrm{mCi})}\end{array}$ \\
\hline 1.0 & 69.0 & $2.46 \times 10^{9}$ & $1.11 \times 10^{3}$ & 1.11 \\
\hline 2.0 & 60.3 & $1.67 \times 10^{9}$ & $7.51 \times 10^{2}$ & 1.86 \\
\hline 3.0 & 58.0 & $1.32 \times 10^{9}$ & $5.96 \times 10^{2}$ & 2.46 \\
\hline 4.0 & 58.0 & $1.04 \times 10^{9}$ & $4.68 \times 10^{2}$ & 2.9 .3 \\
\hline 5.0 & 66.9 & $1.26 \times 10^{9}$ & $5.68 \times 10^{2}$ & 3.50 \\
\hline 6.0 & 69.0 & $1.39 \times 10^{9}$ & $6.29 \times 10^{2}$ & $4: 13$ \\
\hline 7.0 & 69.9 & $1.33 \times 10^{9}$ & $6.01 \times 10^{2}$ & 4.73 \\
\hline 8.0 & 67.4 & $1.29 \times 10^{9}$ & $5.83 \times 10^{2}$ & 5.31 \\
\hline 12.33 & 34.4 & $4.86 \times 10^{8}$ & $2.19 \times 10^{2}$ & 6.19 \\
\hline 13.33 & 68.8 & $1.11 \times 10^{9}$ & $5.02 \times 10^{2}$ & 6.69 \\
\hline 14.33 & 68.5 & $1.02 \times 10^{9}$ & $4.59 \times 10^{2}$ & 7.15 \\
\hline 15.33 & 69.7 & $1.05 \times 10^{9}$ & $4.72 \times 1.0^{2}$ & 7.67 \\
\hline 16.33 & 66.3 & $9.47 \times 10^{8}$ & $4.27 \times 10^{2}$ & 8.05 \\
\hline 23.33 & 32.0 & $3.86 \times 10^{8}$ & $1.74 \times 10^{2}$ & 9.27 \\
\hline 30.33 & 39.4 & $6.61 \times 10^{8}$ & $2.98 \times 1.0^{2}$ & 11.35 \\
\hline 37.33 & 47.8 & $5.17 \times 10^{8}$ & $2.33 \times 10^{2 \mathrm{a}}$ & 12.98 \\
\hline 44.33 & 41.8 & $5.74 \times 10^{8}$ & $2.59 \times 10^{23}$ & 14.79 \\
\hline 51.33 & 39.3 & $9.24 \times 10^{8}$ & $4.16 \times 10^{2 a}$ & 17.70 \\
\hline 58.33 & 33.5 & $5.77 \times 10^{8}$ & $2.60 \times 10^{2 a}$ & 19.52 \\
\hline 65.33 & 39.0 & $1.06 \times 10^{9}$ & $4.76 \times .10^{2 a}$ & 22.85 \\
\hline 72.33 & 43.8 & $1.42 \times 10^{9}$ & $6.42 \times 10^{2 a}$ & 27.34 \\
\hline 79.33 & 33.9 & $1.15 \times 10^{9}$ & $5.17 \times 10^{2 \mathrm{a}}$ & 30.96 \\
\hline 86.33 & 38.2 & $9.76 \times 10^{8}$ & $4.40 \times 10^{2 a}$ & 34.04 \\
\hline 93.33 & 35.2 & $6.84 \times 10^{8}$ & $3.08 \times 10^{2 a}$ & 36.20 \\
\hline 100.33 & 31.5 & $3.33 \times 10^{8}$ & $1.50 \times 10^{2}$ & 37.25 \\
\hline 107.33 & 40.0 & $6.57 \times 10^{8}$ & $2.96 \times 10^{2}$ & 39.32 \\
\hline 118.0 & 42.0 & $2.53 \times 10^{8}$ & $1.14 \times 10^{2}$ & 40.12 \\
\hline
\end{tabular}

${ }^{a}$ Values used to determine the average, $\bar{x}=394 \pm 107$. 
Table A-4. Release rate for ${ }^{85} \mathrm{Kr}$ at $200^{\circ} \mathrm{C}$

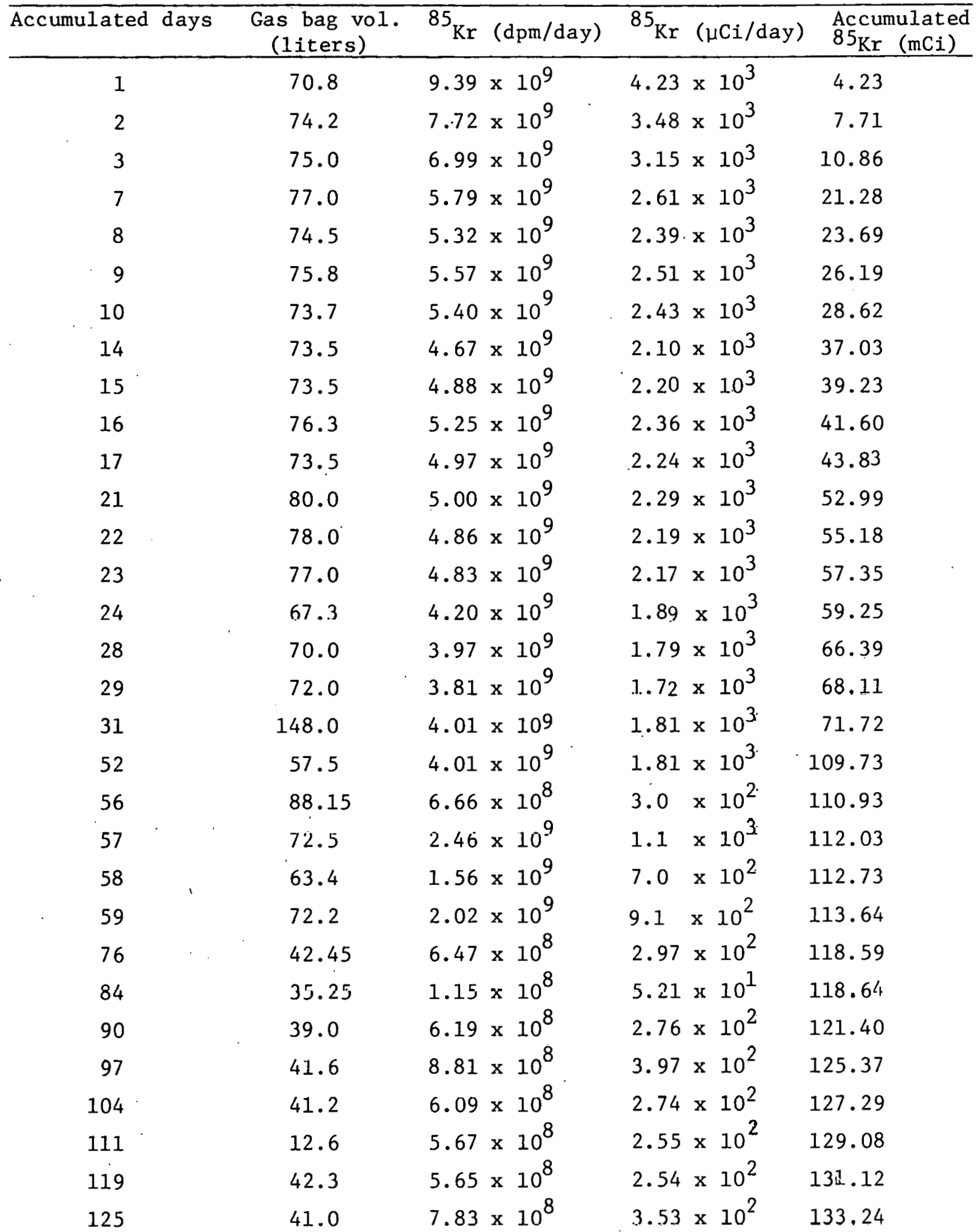


Table A-4 (continued)

\begin{tabular}{|c|c|c|c|c|}
\hline Accumulated days & $\begin{array}{c}\text { Gas bag vol. } \\
\text { (1iters) }\end{array}$ & ${ }^{85} \mathrm{Kr}$ (dpm/day) & ${ }^{85} \mathrm{Kr}(\mu \mathrm{Ci} /$ day $)$ & $\begin{array}{l}\text { Accumulated } \\
85_{\mathrm{Kr} \text { (mCi) }}\end{array}$ \\
\hline 127 & 71.8 & $1.52 \times 10^{9}$ & $6.84 \times 10^{2}$ & 134.61 \\
\hline 128 & 72.0 & $1.77 \times 10^{9}$ & $7.57 \times 10^{2}$ & 135.41 \\
\hline 129 & 77.1 & $1.85 \times 10^{9}$ & $8.33 \times 10^{2}$ & 136.24 \\
\hline 130 & 50.5 & $7.95 \times 10^{8}$ & $3.58 \times 10^{2}$ & 136.60 \\
\hline 1.37 & 53.5 & $2.96 \times 1.10^{8}$ & $1.33 \times 10^{2}$ & 137.53 \\
\hline 144 & 55.5 & $7.94 \times 10^{18}$ & $3.57 \times 10^{2}$ & 140.03 \\
\hline 151 & 45.3 & $9.8 \times 10^{8}$ & $4.4 \times 10^{2}$ & 143.12 \\
\hline 158 & 51.3 & $8.68 \times 10^{8}$ & $3.87 \times 10^{2}$ & 146.19 \\
\hline 165 & 50.2 & $6.21 \times 10^{8}$ & $2.8 \times 10^{2}$ & 148.15 \\
\hline 171 & 57.1 & $8.92 \times 10^{8}$ & $4.82 \times 10^{2}$ & 150.56 \\
\hline 179 & 58.5 & $7.14 \times 10^{8}$ & $3.21 \times 10^{2}$ & 153.13 \\
\hline 186 & 54.3 & $5.53 \times 10^{8}$ & $2.49 \times 10^{2}$ & 154.87 \\
\hline 193 & 52.5 & $2.92 \times 10^{8}$ & $1.32 \times 10^{2}$ & 155.79 \\
\hline 200 & 52.7 & $1.04 \times 10^{8}$ & $4.72 \times 10^{1}$ & 156.12 \\
\hline 204 & 65.2 & $7.16 \times 10^{8}$ & $3.22 \times 10^{2}$ & 157.40 \\
\hline 205 & 60.0 & $8.93 \times 10^{8}$ & $4.02 \times 10^{2}$ & 157.81 \\
\hline 206 & 67.4 & $1.99 \times 10^{9}$ & $8.96 \times 10^{2}$ & 158.70 \\
\hline 207 & 77.8 & $2.51 \times 10^{9}$ & $1.13 \times 10^{3}$ & 159.83 \\
\hline 214 & 50.2 & $4.26 \times 10^{8}$ & $1.92 \times 10^{2}$ & 161.18 \\
\hline 221 & 45.2 & $9.27 \times 10^{7}$ & $4.18 \times 10^{1}$ & 161.47 \\
\hline 228 & 60.0 & $3.73 \times 10^{8}$ & $1.68 \times 10^{2}$ & 162.64 \\
\hline 238 & $5 i .5$ & $6.99 \times 10^{7}$ & $3.15 \times 10^{1}$ & 162.96 \\
\hline 242 & 55.3 & $3.68 \times 10^{8}$ & $1.66 \times 10^{2}$ & 163.62 \\
\hline 243 & 54.5 & $1.65 \times 10^{8}$ & $7.47 \times 10^{1}$ & 164.14 \\
\hline 260 & 60.0 & $2.75 \times 10^{8}$ & $1.24 \times 10^{2}$ & 165.01 \\
\hline 267 & 60.0 & $2.06 \times 10^{8}$ & $9.28 \times 10^{1}$ & .165 .66 \\
\hline 274 & 58.0 & $2.42 \times 1.0^{8}$ & $1.09 \times 10^{2}$ & 166.42 \\
\hline 281 & 58.0 & $6.68 \times 10^{7}$ & $3.01 \times 10^{1}$ & 166.63 \\
\hline 288 & 47.0 & $1.54 \times 10^{8}$ & $6.93 \times 10^{1}$ & 167.11 \\
\hline 295 & 57.0 & $1.16 \times 10^{8}$ & $5.21 \times 10^{1}$ & 167.47 \\
\hline 302 & 58.0 & $9.29 \times 10^{7}$ & $4.18 \times 10^{1}$ & 167.76 \\
\hline 309 & 54.5 & $2.29 \times 10^{8}$ & $1.03 \times 10^{2}$ & 168.48 \\
\hline
\end{tabular}


Table A-4 (continued)

\begin{tabular}{|c|c|c|c|c|}
\hline Accumulated days & $\begin{array}{c}\text { Gas bag vol. } \\
\text { (1iters) }\end{array}$ & ${ }^{85} \mathrm{Kr}(\mathrm{dpm} / \mathrm{day})$ & ${ }^{85} \mathrm{Kr}(\mu \mathrm{Ci} / \mathrm{day})$ & $\begin{array}{l}\text { Accumulated } \\
85 \mathrm{Kr} \text { (mCi) }\end{array}$ \\
\hline 316 & 58.6 & $3.43 \times 10^{8}$ & $1.54 \times 10^{2}$ & 169.56 \\
\hline 323 & 60.0 & $2.14 \times 10^{8}$ & $9.65 \times 10^{1}$ & 170.24 \\
\hline 330 & 58.5 & $3.96 \times 10^{8}$ & $1.78 \times 10^{2}$ & 171.49 \\
\hline 337 & 58.0 & $2.08 \times 10^{8}$ & $9.39 \times 10^{1}$ & 172.15 \\
\hline 345 & 54.0 & $8.5 \times 10^{7}$ & $3.83^{\circ} \times 10^{1}$ & 172.42 \\
\hline 353 & 85.0 & $1.56 \times 10^{8}$ & $7.02 \times 10^{1}$ & 172.98 \\
\hline 360 & 54.2 & $1.17 \times 10^{8}$ & $5.27 \times 10^{1}$ & 173.35 \\
\hline 367 & 42 & $1.56 \times 10^{8}$ & $7.02 \times 10^{1}$ & 173.84 \\
\hline 374 & 48.5 & $2.24 \times 10^{8}$ & $1.01 \times 10^{2}$ & 174.54 \\
\hline 381 & 49.5 & $2.28 \times 10^{8}$ & $1.03 \times 10^{2}$ & 175.26 \\
\hline 388 & 48.0 & $2.21 \times 10^{8}$ & $9.96 \times 10^{1}$ & 175.96 \\
\hline 395 & 45.0 & $2.21 \times 10^{8}$ & $9.98 \times 10^{1}$ & 176.65 \\
\hline 402 & 41.0 & $1.99 \times 10^{8}$ & $9.0 \times 10^{1}$ & 177.29 \\
\hline 409 & 46.0 & $1.94 \times 10^{8}$ & $8.74 \times 10^{1}$ & 177.90 \\
\hline 417 & 45.5 & $1.69 \times 10^{8}$ & $7.6 \times 10^{1}$ & 178.51 \\
\hline 424 & 57.0 & $4.58 \times 10^{8}$ & $2.06 \times 10^{2}$ & 179.95 \\
\hline 430 & 57.0 & $5.34 \times 10^{8}$ & $2.4 \times 10^{2}$ & 1.81 .39 \\
\hline 437 & 57.0 & $4.58 \times 10^{8}$ & $2.06 \times 10^{2}$ & 182.84 \\
\hline 444 & 57.0 & $4.58 \times 10^{8}$ & $2.06 \times 10^{2}$ & 184.28 \\
\hline 451 & 57.0 & $4.58 \times 10^{8}$ & $2.06 \times 10^{2}$ & 185.73 \\
\hline 458 & 57.0 & $4.58 \times 10^{8}$ & $2.06 \times 10^{2}$ & 187.17 \\
\hline 465 & 78.5 & $2.85 \times 10^{8}$ & $1.28 \times 10^{2}$ & 188.06 \\
\hline 472 & 62.2 & $3.55 \times 10^{8}$ & $1.59 \times 10^{2}$ & 189.18 \\
\hline 479 & 52.2 & $3.72 \times 10^{8}$ & $1.68 \times 10^{2 a}$ & 190.36 \\
\hline 486 & 122.1 & $3.51 \times 10^{8}$ & $1.58 \times 10^{2 a}$ & 191.47 \\
\hline 493 & 122.1 & $3.51 \times 10^{8}$ & $1.58 \times 10^{2 \mathrm{a}}$ & 192.57 \\
\hline 500 & 53.0 & $4.31 \times 10^{8}$ & $1.94 \times 10^{2 \mathrm{a}}$ & 193.93 \\
\hline 507 & 55.2 & $4.16 \times 10^{8}$ & $1.87 \times 10^{2 a}$ & 195.24 \\
\hline 514 & 58.0 & $3.63 \times 10^{8}$ & $1.63 \times 10^{2 \mathrm{a}}$ & 196.39 \\
\hline 521 & 58.0 & $3.63 \times 10^{8}$ & $1.63 \times 10^{2 \mathrm{a}}$ & 197.53 \\
\hline 528 & 59.0 & $4.14 \times 10^{8}$ & $1.86 \times 10^{2 a}$ & 198.84 \\
\hline
\end{tabular}


Table A-4 (continued)

\begin{tabular}{cccccc}
\hline Accumulated days & $\begin{array}{c}\text { Gas bag vol. } \\
\text { (1iters) }\end{array}$ & ${ }^{85} \mathrm{Kr}$ (dpm/day) & ${ }^{85} \mathrm{Kr}$ ( $\left.\mu \mathrm{Ci} / \mathrm{day}\right)$ & $\begin{array}{c}\text { Accumulated } \\
85 \mathrm{Kr}(\mathrm{mC})\end{array}$ \\
\hline 535 & 62.0 & $5.59 \times 10^{8}$ & $2.52 \times 10^{2 \mathrm{a}}$ & 200.61 \\
554 & 63.3 & $2.86 \times 10^{8}$ & $1.29 \times 10^{2 \mathrm{a}}$ & 201.51 \\
\hline
\end{tabular}

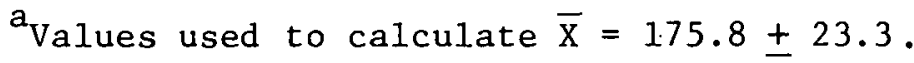


Table A-5. Release rate for ${ }^{85} \mathrm{Kr}$ at $300^{\circ} \mathrm{C}$

\begin{tabular}{|c|c|c|c|c|}
\hline Accumulated days & $\begin{array}{c}\text { Gas bag vol. } \\
\text { (1iters) }\end{array}$ & ${ }^{85} \mathrm{Kr}(\mathrm{dpm} / \mathrm{day})$ & ${ }^{85} \mathrm{Kr}(\mu \mathrm{Ci} / \mathrm{day})$ & $\begin{array}{l}\text { Accumulated } \\
85_{\mathrm{Kr} \text { (mCi) }}\end{array}$ \\
\hline 1 & 62.0 & $1.07 \times 10^{10}$ & $4.83 \times 10^{3}$ & 4.83 \\
\hline 2 & 63.0 & $8.35 \times 10^{9}$ & $3.76 \times 10^{3}$ & 8.59 \\
\hline 3 & 64.0 & $9.49 \times 10^{9}$ & $4.28 \times 10^{3}$ & 12.88 \\
\hline 4 & 64.0 & $1.05 \times 10^{10}$ & $4.73 \times 10^{3}$ & 17.61 \\
\hline 5 & 67.0 & $1.11 \times 10^{10}$ & $5.02 \times 10^{3}$ & 22.64 \\
\hline 6 & 67.0 & $1.17 \times 10^{10}$ & $5.27 \times 10^{3}$ & 27.91 \\
\hline 7 & 67.0 & $1.20 \times 10^{10}$ & $5.42 \times 10^{3}$ & 33.33 \\
\hline 8 & 58.5 & $1.13 \times 10^{10}$ & $5.08 \times 10^{3}$ & 38.42 \\
\hline 9 & 63.0 & $1.13 \times 10^{10}$ & $5.10 \times 10^{3}$ & 43.52 \\
\hline 10 & 58.0 & $1.19 \times 10^{10}$ & $5.38 \times 10^{3}$ & 48.89 \\
\hline 11 & 76.0 & $1.19 \times 10^{10}$ & $5.37 \times 10^{3}$ & 54.27 \\
\hline 12 & 83.0 & $1.29 \times 10^{10}$ & $5.80 \times 10^{3}$ & 60.07 \\
\hline 13 & 51.0 & $1.15 \times 10^{10}$ & $5.18 \times 10^{3}$ & 65.25 \\
\hline 14 & 39.0 & $1.03 \times 10^{10}$ & $4.63 \times 10^{3}$ & 69.88 \\
\hline 15 & 62.5 & $1.16 \times 10^{10}$ & $5.24 \times 10^{3}$ & 75.12 \\
\hline 16 & 66.0 & $1.22 \times 10^{10}$ & $5.53 \times 10^{3}$ & 80.65 \\
\hline 17 & 64.0 & $1.16 \times 10^{10}$ & $5.24 \times 10^{3}$ & 85.89 \\
\hline 21 & 87.0 & $1.36 \times 10^{10}$ & $6.12 \times 10^{3}$ & 92.01 \\
\hline 22 & 74.5 & $8.98 \times 10^{9}$ & $4.05 \times 10^{3}$ & 96.05 \\
\hline 23 & 74.5 & $9.44 \times 10^{9}$ & $4.25 \times 10^{3}$ & 100.31 \\
\hline 24 & 74.5 & $9.44 \times 10^{9}$ & $4.25 \times 10^{3}$ & 104.56 \\
\hline 27 & 123.0 & $9.45 \times 10^{9}$ & $4.26 \times 10^{3}$ & 108.81 \\
\hline 28 & 84.5 & $1.38 \times 10^{10}$ & $6.24 \times 10^{3}$ & 115.05 \\
\hline 29 & 81.0 & $1.16 \times 10^{10}$ & $5.23 \times 10^{3}$ & 120.29 \\
\hline 30 & 77.5 & $1.11 \times 10^{10}$ & $4.99 \times 10^{3}$ & 125.28 \\
\hline 31 & 83.5 & $1.12 \times 10^{10}$ & $5.07 \times 10^{3}$ & 130.34 \\
\hline 35 & 288.0 & $1.33 \times 10^{10}$ & $5.98 \times 10^{3}$ & 154.26 \\
\hline 36 & 110.0 & $1.16 \times 10^{10}$ & $5.22 \times 10^{3}$ & 159.48 \\
\hline 37 & 111.0 & $1.1 \times 10^{10}$ & $4.96 \times 10^{3}$ & 164.45 \\
\hline 38 & 108.5 & $1.08 \times 10^{10}$ & $4.85 \times 10^{3}$ & 169.29 \\
\hline 41 & $220^{\prime}$ & $9.8 \times 10^{9}$ & $4.42 \times 10^{3}$ & 182.56 \\
\hline
\end{tabular}


Table A-5 (continued)

\begin{tabular}{|c|c|c|c|c|}
\hline$\overline{\text { Accumulated days }}$ & $\begin{array}{c}\text { Gas bag vol. } \\
\text { (liters) }\end{array}$ & ${ }^{85} \mathrm{Kr}(\mathrm{dpm} / \mathrm{day})$ & ${ }^{85} \mathrm{Kr}(\mu \mathrm{Ci} / \mathrm{day}$ & $\begin{array}{l}\text { y) } 8 c c u m u l a t e d \\
85_{\mathrm{Kr}}(\mathrm{mCi})\end{array}$ \\
\hline 42 & 113.0 & $1.04 \times 10^{10}$ & $4.69 \times 10^{3}$ & 187.25 \\
\hline 43 & 113.0 & $1.01 \times 10^{10}$ & $4.55 \times 10^{3}$ & 191.81 \\
\hline 44 & 119.0 & $1.01 \times 10^{10}$ & $4.56 \times 10^{3}$ & 196.37 \\
\hline 45 & 116.0 & $1.02 \times 10^{10}$ & $4.63 \times 10^{3}$ & 200.99 \\
\hline 48 & 264.0 & $9.83 \times 10^{9}$ & $4.42 \times 10^{3}$ & 211.28 \\
\hline 49 & 1008 & $4.45 \times 10^{y}$ & $4.25 \times 10^{3}$ & 218.53 \\
\hline 50 & 119.0 & $9.49 \times 10^{9}$ & $4.28 \times 10^{3}$ & 222.81 \\
\hline 51 & 124.0 & $9.63 \times 10^{9}$ & $4.34 \times 10^{3}$ & 227.15 \\
\hline 52 & 118.0 & $9.10 \times 10^{9}$ & $4.09 \times 10^{3}$ & 231.25 \\
\hline 55 & 249.0 & $9.56 \times 10^{9}$ & $4.31 \times 10^{3 a}$ & 235.55 \\
\hline 56 & 121.5 & $9.09 \times 10^{9}$ & $4.09 \times 10^{3 a}$ & 239.65 \\
\hline 57 & 121.0 & $9.09 \times 10^{9}$ & $4.09 \times 1.0^{3 a}$ & 243.74 \\
\hline 58 & 120.0 & $9.13 \times 10^{9}$ & $4.11 \times 10^{3 a}$ & 247.85 \\
\hline 59 & 119.0 & $9.32 \times 10^{9}$ & $4.20 \times 10^{3 a}$ & 252.06 \\
\hline 62 & 265 & $9.28 \times 10^{9}$ & $4.18 \times 10^{3 a}$ & 264.59 \\
\hline 63 & 113 & $8.87 \times 10^{9}$ & $3.99 \times 10^{3 a}$ & 268.59 \\
\hline 64 & 141 & $8.81 \times 10^{9}$ & $3.97 \times 10^{3 \mathrm{a}}$ & 272.56 \\
\hline 65 & 131 & $9.05 \times 10^{9}$ & $4.08 \times 10^{3 a}$ & 276.63 \\
\hline 66 & 133 & $8.72 \times 10^{9}$ & $3.93 \times 10^{3 a}$ & 280.56 \\
\hline
\end{tabular}

${ }^{a}$ Values used to calculate the average, $\bar{x}=4095 \pm 82$. 
Table A-6. Release rate for ${ }^{3} \mathrm{H}$ at ambient temperature $\left(\sim 30^{\circ} \mathrm{C}\right)$

\begin{tabular}{|c|c|c|c|}
\hline Accumulated days & ${ }^{3} \mathrm{H}$ (dpm/day) & $3_{\mathrm{H}}(\mu \mathrm{Ci} /$ day $)$ & $\begin{array}{l}\text { Accumulated } \\
3_{\mathrm{H}}(\mu \mathrm{C} i)\end{array}$ \\
\hline 1 & $6.67 \times 10^{6}$ & 3.01 & 3.01 \\
\hline 2 & $1.70 \times 10^{6}$ & 0.77 & 3.77 \\
\hline 3 & $8.37 \times 10^{5}$ & 0.38 & 4.15 \\
\hline 4 & $8.79 \times 10^{5}$ & 0.40 & 4.55 \\
\hline 5 & $6.10 \times 10^{5}$ & 0.27 & 4.82 \\
\hline 6 & $5.49 \times 10^{5}$ & 0.25 & 5.07 \\
\hline 7 & $6.59 \times 10^{5}$ & 0.30 & $5.3 i$ \\
\hline 8 & $2.76 \times 10^{5}$ & 0.12 & 5.49 \\
\hline 9 & $3.81 \times 10^{5}$ & 0.17 & 5.66 \\
\hline 10 & $2.42 \times 10^{5}$ & 0.11 & 5.77 \\
\hline 11 & $2.17 \times 10^{5}$ & 0.10 & 5.87 \\
\hline 12 & $8.31 \times 10^{5}$ & 0.37 & 6.24 \\
\hline 19 & $3.85 \times 10^{4}$ & $0.017^{a}$ & 6.36 \\
\hline 25 & $3.27 \times 10^{5}$ & 0.147 & 7.39 \\
\hline 32 & $5.78 \times 10^{4}$ & $0.026^{\mathrm{a}}$ & 7.57 \\
\hline 39 & $8.17 \times 10^{4}$ & $0.037^{a}$ & 7.82 \\
\hline 46 & $5.47 \times 10^{4}$ & $0.025^{a}$ & 8.00 \\
\hline 53 & $5.45 \times 10^{4}$ & $0.024^{\mathrm{a}}$ & 8.19 \\
\hline 59 & $5.88 \times 10^{4}$ & $0.027^{a}$ & 8.35 \\
\hline 70 & $3.21 \times 10^{4}$ & $0.014^{\mathrm{a}}$ & 8.46 \\
\hline
\end{tabular}

${ }^{a}$ Values used to calculate the average, $\bar{x}=0.024 \pm 0.007$. 
Table A-7. Release rate for ${ }^{3} \mathrm{H}$ at $100^{\circ} \mathrm{C}$

\begin{tabular}{|c|c|c|c|}
\hline Accumulated days & ${ }^{3} \mathrm{H}(\mathrm{dpm} / \mathrm{day})$ & ${ }^{3} \mathrm{H}(\mu \mathrm{Ci} /$ day $)$ & $\begin{array}{l}\text { Accumulated } \\
3 \mathrm{H}(\mu \mathrm{Ci})\end{array}$ \\
\hline 1 & $7.23 \times 10^{5}$ & $3.26 \times 10^{-1}$ & 0.326 \\
\hline 2 & $4.18 \times 10^{5}$ & $1.33 \times 10^{-1}$ & 0.514 \\
\hline 3 & $4.27 \times 10^{5}$ & $1.92 \times 10^{-1}$ & 0.706 \\
\hline 4 & $3.857 \times 10^{5}$ & $1.737 \times 10^{-1}$ & 0.880 \\
\hline 5 & 5.507 15 $10^{5}$ & 2.48 या $10^{-1}$ & 1.120 \\
\hline 6 & $8.411 \times 10^{5}$ & $3.788 \times 10^{-1}$ & 1.507 \\
\hline 7 & $6.248 \times 10^{5}$ & $2.815 \times 10^{-1}$ & 1.788 \\
\hline 8 & $3.971 \times 10^{5}$ & $1.789 \times 10^{-1}$ & 1.967 \\
\hline 9 & $3.297 \times 10^{5}$ & $1.486 \times 10^{-1}$ & 2.116 \\
\hline 10 & $2.941 \times 105$ & $1.325 \times 10^{-1}$ & 2.248 \\
\hline 13 & $6.98 \times 1.0^{5}$ & $3.1 .5 \times 1.0^{-1}$ & 2.352 \\
\hline 14.0 & $2.63 \times 10^{5}$ & $1.18 \times 10^{-1}$ & 2.786 \\
\hline 15 & $2.34 \times 10^{5}$ & $1.01 \times 10^{-1}$ & 2.887 \\
\hline 16 & $1.97 \times 10^{5}$ & $8.87 \times 10^{-2}$ & 2.976 \\
\hline 17 & $1.80 \times 10^{5}$ & $0.12 \times 10^{-2}$ & 3.057 \\
\hline 17.33 & $2.04 \times 10^{5}$ & $9.17 \times 10^{-2}$ & 3.087 \\
\hline 21.33 & $3.95 \times 10^{5}$ & $1.78 \times 10^{-1}$ & 3.799 \\
\hline 22.33 & $5.47 \times 10^{5}$ & $2.46 \times 10^{-1}$ & 4.045 \\
\hline 24.33 & $2.21 \times 10^{5}$ & $9.93 \times 10^{-2}$ & 4.144 \\
\hline 25.33 & $7.06 \times 10^{5}$ & $3.18 \times 10^{-1}$ & 4.46 \\
\hline 29 & $6.33 \times 10^{3}$ & $2.85 \times 10^{-1}$ & 5.509 \\
\hline 30 & $2.10 \times 10^{6}$ & $9.47 \times 10^{-1}$ & 6.456 \\
\hline 31 & $1.25 \times 10^{6}$ & $5.65 \times 10^{-1}$ & 7.021 \\
\hline 32 & $9.03 \times 10^{5}$ & $4.07 \times 10^{-1}$ & 7.428 \\
\hline 32.33 & $7.07 \times 105$ & $3.18 \times 10^{-1}$ & 7.533 \\
\hline 36 & $1.17 \times 10^{5}$ & $5.29 \times 10^{-2 a}$ & 7.727 \\
\hline 37 & $3.43 \times 105$ & $1.54 \times 10^{-1 \mathrm{a}}$ & 7.881 \\
\hline 38 & $2.90 \times 10^{5}$ & $1.31 \times 10^{-1 a}$ & 8.012 \\
\hline 39 & $1.96 \times 10^{5}$ & $8.84 \times 10^{-2 a}$ & 8.100 \\
\hline 39.33 & $1.69 \times 10^{5}$ & $7.59 \times 10^{-2 a}$ & 8.125 \\
\hline
\end{tabular}


Table A-7 (continued)

\begin{tabular}{llll}
\hline Accumulated days & $3_{\mathrm{H}}(\mathrm{dpm} / \mathrm{day})$ & ${ }^{3} \mathrm{H}(\mu \mathrm{Ci} / \mathrm{day})$ & $\begin{array}{l}\text { Accumulated } \\
3_{\mathrm{H}}(\mu \mathrm{C})\end{array}$ \\
\hline 46.33 & $1.66 \times 10^{4}$ & $7.49 \times 10^{-3 \mathrm{a}}$ & 8.178 \\
53.33 & $1.93 \times 10^{4}$ & $8.70 \times 10^{-3 a}$ & 8.239 \\
60.33 & $2.72 \times 10^{4}$ & $1.23 \times 10^{-2 a}$ & 8.325 \\
67.33 & $3.09 \times 10^{4}$ & $1.39 \times 10^{-2 a}$ & 8.422 \\
78 & $3.56 \times 10^{4}$ & $1.61 \times 10^{-2 a}$ & 8.534 \\
\hline
\end{tabular}

${ }^{a}$ Values used to calculate the average, $\bar{x}=0.056 \pm 0.039$ 
Table A-8. Release rate for ${ }^{3} \mathrm{H}$ at $150^{\circ} \mathrm{C}$

\begin{tabular}{|c|c|c|c|}
\hline Accumulated days & $3_{\mathrm{H}}(\mathrm{dpm} /$ day $)$ & ${ }^{3} \mathrm{H}(\mu \mathrm{Ci} /$ day $)$ & $\begin{array}{l}\text { Accumulated } \\
3_{\mathrm{H}}(\mu \mathrm{C} i)\end{array}$ \\
\hline 1 & $3.10 \times 10^{4}$ & $1,40 \times 10^{-2}$ & $n .1$ \\
\hline ?. & $5.85 \times 10^{5}$ & $2.63 \times 10^{-1}$ & 0.28 \\
\hline 3 & $4.51 \times 10^{5}$ & $2.03 \times 10^{-1}$ & 0.48 \\
\hline$\cdot 4$ & $9.25 \times 10^{3}$ & $4.17 \times 10^{-3}$ & 0.48 \\
\hline 5 & $5.89 \times 10^{5}$ & $2.65 \times 10^{-1}$ & 0.75 \\
\hline 6 & $6.64 \times 10^{5}$ & $2.99 \times 10^{-1}$ & $1 . n ?$ \\
\hline 7 & $5.64 \times 10^{5}$ & $2.54 \times 10^{-1}$ & 1.32 \\
\hline 8 & $4.10 \times 10^{5}$ & $1.85 \times 10^{-1}$ & 1.57 \\
\hline 12 & $3.00 \times 10^{5}$ & $1.35 \times 10^{-1}$ & 2.14 \\
\hline 13 & $8.46 \times 10^{5}$ & $3.81 \times 10^{-1}$ & 2.52 \\
\hline 14 & $8.61 \times 10^{5}$ & $3.88 \times 10^{-1}$ & 2.90 \\
\hline 15 & $7.38 \times 10^{5}$ & $3.32 \times 10^{-1}$ & 3.32 \\
\hline 15.33 & $5.66 \times 10^{5}$ & $2.55 \times 10^{-1}$ & 3.32 \\
\hline 22.33 & $2.18 \times 10^{6}$ & $9.83 \times 10^{-1}$ & 10.20 \\
\hline 29.33 & $6.1 \times 10^{6}$ & $2.75 \times 10^{0}$ & 29.17 \\
\hline 36.33 & $4.18 \times 10^{6}$ & $1.88 \times 10^{\circ}$ & 42.36 \\
\hline 4.3 .35 & $1.86 \times 10^{6}$ & $8.36 \times 10^{-10}$ & 48.22 \\
\hline 50.33 & $1.36 \times 10^{6}$ & $6.15 \times 10^{-1 a}$ & 52.52 \\
\hline 57.33 & $1.87 \times 10^{6}$ & $8.41 \times 10^{-1 \mathrm{a}}$ & 58.42 \\
\hline 64.33 & $1.13 \times 10^{6}$ & $5.09 \times 10^{-1 \mathrm{a}}$ & 61.97 \\
\hline 71.33 & $8.0 \times 10^{6}$ & $3.61 \times 1 u^{n}$ & 87.20 \\
\hline 78.33 & $6.09 \times 10^{5}$ & $2.74 \times 10^{-1 a}$ & 89.11 \\
\hline 85.33 & $4.18 \times 10^{5}$ & $1.88 \times 10^{-1 a}$ & 90.44 \\
\hline 92.33 & $2.85 \times 10^{5}$ & $1.29 \times 10^{-1 \mathrm{a}}$ & 91.34 \\
\hline 99.33 & $8.20 \times 10^{4}$ & $3.69 \times 10^{-2 a}$ & 91.60 \\
\hline 106.33 & $4.73 \times 10^{5}$ & $2.73 \times 10^{-1 a}$ & 93.09 \\
\hline 118 & $1.24 \times 10^{5}$ & $5.59 \times 10^{-2 a}$ & 93.48 \\
\hline
\end{tabular}

${ }^{a}$ Values used to calculate the average, $\bar{x}=0.376 \pm 0.218$ 
Table A-9. Release rate for ${ }^{3} \mathrm{H}$ at $200^{\circ} \mathrm{C}$

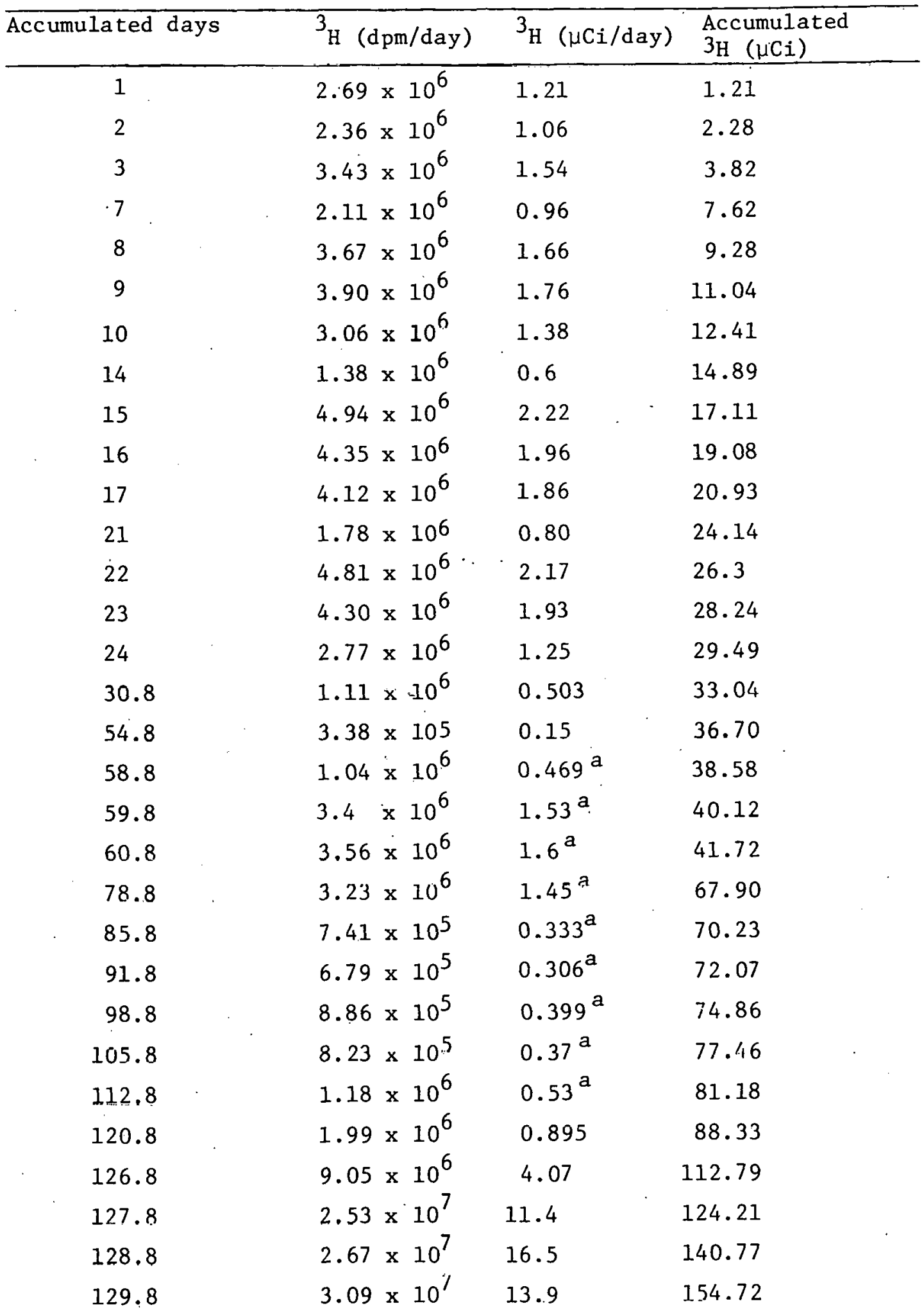


Table A-9 (continued)

\begin{tabular}{|c|c|c|c|c|}
\hline Accumulated days & ${ }^{3} \mathrm{H}(\mathrm{dpm} / \mathrm{day})$ & $3_{\mathrm{H}}$ & $(\mu \mathrm{C} i /$ day $)$ & $\begin{array}{l}\text { Accumulated } \\
3_{\mathrm{H}}(\mu \mathrm{C} i)\end{array}$ \\
\hline 136.8 & $2.51 \times 10^{6}$ & & 1.13 & 162.64 \\
\hline 143.8 & $1.56 \times 10^{6}$ & & 0.703 & 167.57 \\
\hline 150.8 & $1.01 \times 10^{6}$ & & 0.45 & 170.74 \\
\hline 157.8 & $9.18 \times 10^{5}$ & & 0.413 & 173.64 \\
\hline 164.8 & $1.00 \times 10^{6}$ & & 0.452 & 176.80 \\
\hline 171.8 & $1.1 .3 \times 10^{6}$ & & 0.531 & 180.53 \\
\hline 177.8 & $1.51 \times 10^{6}$ & & 0.681 & 104.62 \\
\hline 185.8 & $1,74 \times 10^{6}$ & & 0.783 & 190.88 \\
\hline 192.8 & $2.22 \times 10^{6}$ & & 1.00 & 197.90 \\
\hline 199.8 & $2.43 \times 10^{6}$ & & 1.09 & 205.57 \\
\hline 207 & $6.92 \times 10^{6}$ & & 3.12 & 227.38 \\
\hline 214 & $2.83 \times 10^{6}$ & & 1.28 & 236.32 \\
\hline 221 & $7.13 \times 10^{6}$ & & 3.21 & 258.81 \\
\hline 228 & $7.40 \times 10^{5}$ & & 0.333 & 261.15 \\
\hline 235 & $5.36 \times 10^{5}$ & & 0.241 & 262.83 \\
\hline 242 & $3.63 \times 10^{6}$ & & 1.64 & 214.29 \\
\hline 249 & $1.50 \times 10^{7}$ &. & 7.02 & 344.48 \\
\hline 251 & $9.44 \times 10^{6}$ & & 4.25 & 361.49 \\
\hline 255 & $1.43 \times 10^{6}$ & & 0.644 & 368.57 \\
\hline 266 & $1.85 \times 10^{6}$ & & 0.833 & 369.40 \\
\hline 2.73 & $1.55 \times 10^{6}$ & & 0.699 & 370.01 \\
\hline 280 & $1.66 \times 10^{6}$ & & 0.748 & 370.758 \\
\hline 287 & $1.16 \times 10^{7}$ & & 5.22 & $40 \overline{7} .329$ \\
\hline 294 & $1.01 \times 10^{6}$ & & 0.455 & 410.514 \\
\hline 30.1 & $1.75 \times 10^{7}$ & & 7.90 & 465.801 \\
\hline 308 & $6.69 \times 10^{6}$ & & 3.02 & 486.916 \\
\hline 315 & $1.63 \times 1.0^{6}$ & & 0.732 & 492.043 \\
\hline 322 & $8.54 \times 10^{6}$ & & 3.85 & 518.97 \\
\hline 329 & $1.89 \times 10^{6}$ & & 0.851 & 524.93 \\
\hline 336 & $3.44 \times 10^{6}$ & & 1.55 & 535.77 \\
\hline 343 & $1.7 \times 10^{6}$ & & 0.767 & 541.14 \\
\hline 350 & $2.27 \times 10^{6}$ & & 1.02 & 548.29 \\
\hline
\end{tabular}


Table A-9 (continued)

\begin{tabular}{|c|c|c|c|}
\hline Accumulated days & $3_{\mathrm{H}}$ (dpm/day) & ${ }^{3} \mathrm{H}(\mu \mathrm{Ci} / \mathrm{day})$ & $\begin{array}{l}\text { Accumulated } \\
3 \mathrm{H}(\mu \mathrm{Ci})\end{array}$ \\
\hline 357 & $5.11 \times 10^{6}$ & 2.3 & 566.7 \\
\hline 361 & $2.19 \times 10^{6}$ & 0.988 & 573.62 \\
\hline 367 & $2.05 \times 10^{6}$ & 0.923 & 580.08 \\
\hline 374 & $2.05 \times 10^{6}$ & 0.923 & 586.55 \\
\hline 381 & $2.05 \times 10^{6}$ & 0.923 & 593.01 \\
\hline 388 & $2.05 \times 10^{6}$ & 0.923 & 599.47 \\
\hline 395 & $2.05 \times 10^{6}$ & 0.923 & 605.94 \\
\hline 402 & $2.05 \times 10^{6}$ & 0.923 & 612.40 \\
\hline 409 & $2.05 \times 10^{6}$ & 0.923 & 618.87 \\
\hline 417 & $1.79 \times 10^{6}$ & 0.808 & 625.33 \\
\hline 424 & $2.05 \times 10^{6}$ & 0.923 & 631.79 \\
\hline 430 & $2.39 \times 10^{6}$ & 1.08 & 638.26 \\
\hline 437 & $2.05 \times 10^{6}$ & 0.923 & 644.72 \\
\hline 441 & $2.05 \times 10^{6}$ & 0.923 & 651.19 \\
\hline 448 & $2.05 \times 10^{6}$ & 0.923 & 657.65 \\
\hline 455 & $1.91 \times 10^{6}$ & 0.859 & 663.66 \\
\hline 462 & $1.01 \times 10^{6}$ & 0.457 & 666.86 \\
\hline 469 & $6.17 \times 10^{5}$ & 0.278 & 668.81 \\
\hline 476 & $7.25 \times 10^{5}$ & 0.326 & 671.09 \\
\hline 490 & $9.83 \times 10^{5}$ & 0.443 & 677.30 \\
\hline 497 & $9.52 \times 10^{5}$ & 0.429 & 680.30 \\
\hline 504 & $1.19 \times 10^{6}$ & 0.538 & 684.06 \\
\hline 518 & $5.34 \times 10^{5}$ & 0.241 & 687.43 \\
\hline 528 & $8.22 \times 10^{5}$ & 0.370 & 690.02 \\
\hline 535 & $1.72 \times 10^{6}$ & 0.776 & 695.45 \\
\hline 554 & $1.65 \times 10^{6}$ & 0.746 & 700.67 \\
\hline
\end{tabular}

avalues used to determine average, $\bar{x}=0.749 \pm 0.388$ 
Table A-10. Release rate for ${ }^{3} \mathrm{H}$ at $300^{\circ} \mathrm{C}$

\begin{tabular}{|c|c|c|c|}
\hline Accumulated days & $3_{H}(\mathrm{dpm} / \mathrm{day})$ & ${ }^{3} \mathrm{H}(\mu \mathrm{Ci} /$ day $)$ & $\begin{array}{l}\text { Accumulated } \\
3_{\mathrm{H}}(\mu \mathrm{C} i)\end{array}$ \\
\hline 1 & $9.81 \times 10^{7}$ & 44.2 & 44.17 \\
\hline 2 & $2.38 \times 10^{7}$ & 10.7 & 54.89 \\
\hline 3 & $1.5 \times 10^{7}$ & 67.5 & 61.64 \\
\hline 4 & $1.6 \times 10^{7}$ & 73.1 & 68.95 \\
\hline 5 & $2.5 \times 10^{7}$ & 11.3 & 80.26 \\
\hline 6 & 2.87 \& $10^{7}$ & 13.0 & 43.21 \\
\hline 7 & $2.94 \times 10^{j}$ & 13.2 & 106.46 \\
\hline 8 & $2.27 \times 10^{7}$ & 10.2 & 116.68 \\
\hline 9 & $2.56 \times 10^{7}$ & 11.5 & 128.22 \\
\hline 10 & $2.15 \times 10^{7}$ & 9.66 & $1,37.88$ \\
\hline 11 & $3.5 \times 10^{7}$ & 15.8 & 153.65 \\
\hline 12 & $2.53 \times 10^{7}$ & 11.4 & 165.04 \\
\hline 13 & $2.19 \times 10^{7}$ & 9.88 & 174.92 \\
\hline 14 & $1.37 \times 10^{7}$ & 6.17 & 181.09 \\
\hline 15 & $1.96 \times 10^{7}$ & 8.81 & 189.90 \\
\hline 16 & $2.53 \times 10^{7}$ & $11.41^{a}$ & 201.31 \\
\hline 17 & $2.68 \times 10^{7}$ & $12.06^{\mathrm{a}}$ & 213.37 \\
\hline 18 & $1.36 \times 10^{7}$ & $5.01^{a}$ & 237.79 \\
\hline 22 & $2.1 \times 10^{7}$ & $9.48^{a}$ & 272.89 \\
\hline 28 & $4.05 \times 10^{7}$ & $18 \cdot 3^{a}$ & 339.27 \\
\hline 36 & $4.61 \times 10^{7}$ & $20.7^{a}$ & 487.08 \\
\hline 42 & $6.43 \times 10^{7}$ & $28.9^{a}$ & 612.35 \\
\hline 49 & $6.42 \times 10^{7}$ & $28.9^{a}$ & 815.06 \\
\hline 56 & $6.42 \times 10^{7}$ & $28.9^{a}$ & 1017.79 \\
\hline 63 & $6.42 \times 10^{7}$ & $28.9^{a}$ & 1220.51 \\
\hline 66 & $6.42 \times 1.0^{7}$ & $28.9^{a}$ & 1307.39 \\
\hline
\end{tabular}

avalues used to determine average, $\bar{x}=19.3 \pm 6.7$. 
ORNL/TM-6409

Dist. Category UC-77

\section{INTERNAL DISTRIBUTION}

1. B. J. Baxter, GAC/ORNL

2. R. J. Beaver

3. E. C. Beahm

4. R. A. Bradley

5. A. J. Caputo

6. J. A. Carpenter, Jr.

7. W. L. Carter

8. C. F. Coleman

9. J. L. Collins

10. W. P. Eatherly

11. D. E. Ferguson

12-15. C. L. Fitzgerald

16. F. E. Harrington

17. C. C. Haws

18. R. M. Hill

19. F. J. Homan

20. J. D. Jenkins

21. D. R. Johnson

22-29. P. R. Kasten

30. D. J. Kington

31. W. L. Lackey

32. C. E. Lamb

33. K. H. Lin

34. T. B. Lindemer

35. E. L. Long

36. R. A. Lorenz

37-38. A. L. Lotts

39. J. E. Mack

40. A. P. Malinauskas
41-42. K. J. Notz

43. A. R. O1sen

44. H. A. Parker

45. W. H. Pechin

46. D. P. Reid

47. J. E. Rushton

48. T. F. Scanlan

49. H. C. Savage

50. C. D. Scott

51. J. H. Shaffer

52-56. R. J. Shannon

57. D. P. Stinton

58. T. N. Tiegs

59. D. B. Trauger

60. V. C. A. Vaughen

61. J. R. Weir

62. W. R. Williams

63-64. R. G. Wymer

65-66. Central Research Library

67. Laboratory Records

68. Laboratory Records - RC

69. ORNL Patent Section

70. G. R. Choppin (Consultant)

71. L. J. Colby (Consultant)

72. E. L. Gaden (Consultant)

73. L. E. Swabb (Consultant)

74. K. D. Timmerhaus (Consultant)

\section{EXI'ERNAL DISTRIBITTION}

75. Research and Technical Support Division, DOE, ORO, P. O. Box E, Oak Ridge, TN 37830

76. Director, Reactor Division, DOE, ORO, P. O. Box E, Oak Ridge, TN 37830

77-78. Director, Division of Reactor Development and Demonstration, DOE, Washington, D. C. 20545

79-255. Given distribution as shown in TID-4500 under Gas-Cooled Reactor Technolugy category (25 copies - NTIS) 